\title{
Toxic effects of silver nanoparticles in mammals - does a risk of neurotoxicity exist?
}

\author{
Joanna Skalska, Lidia Strużyńska \\ Laboratory of Pathoneurochemistry, Department of Neurochemistry, Mossakowski Medical Research Centre, Polish Academy \\ of Sciences, Warsaw, Poland
}

\begin{abstract}
Over the last decade, silver nanoparticles have become an important class of nanomaterials utilized in the development of new nanotechnologies. Despite the fact that nanosilver is used in many commercial applications, our knowledge about its associated risks is incomplete. Although a number of studies have been undertaken to better understand the impact of silver nanoparticles on the environment, aquatic organisms and cell lines, little is known about their side effects in mammalian organisms. This review summarizes relevant data and the current state of knowledge regarding toxicity of silver nanoparticles in mammals, as well as the accumulated evidence for potent neurotoxic effects. The influence of nanosilver on the central nervous system is significant because of evidence indicating that it accumulates in mammalian brain tissue.
\end{abstract}

Key words: silver nanoparticles, neurotoxicity, mammals, nanotoxicology.

\section{Introduction}

Silver is well known for its many industrial applications such as soldering, electrical conduction and plating applications. Additionally, this metal is used in the production of jewellery, cutlery, coins, medical instruments and photographic materials. In medical applications silver is included in wound dressings, urinary catheters and other medical devices, because of the ability of silver ions to inhibit growth of bacteria and fungi. Known for millennia, the antimicrobial effect of ionic silver arises from its ability to generate reactive oxygen species (ROS) and to inactivate microbial enzymes $[19,75,88]$.
In addition to antibacterial activity, silver (particularly in the form of soluble silver compounds) exerts toxic effects in animals and humans. Acute symptoms of over-exposure to silver ions in humans include damage to the gastrointestinal tract, abdominal pain, diarrhea and convulsions [113]. The most common adverse effects associated with chronic exposure to silver in humans are discoloration of eyes (argyrosis) and pigmentation of the skin and mucous membranes, which turn irreversibly gray or bluish-gray (argyria). Argyria has been reported mainly in workers associated with mining, manufacturing or packing of silver $[8,28,96]$. Moreover, animal studies have revealed that prolonged administration 
of silver ions in low doses leads to accumulation of silver granules in eyes, heart enlargement, anemia and pathological changes to the liver and kidneys $[28,113]$.

Recently, a resurgence in commercial applications of silver has occurred due to the development of nanotechnologies which make extensive use of silver in the form of nanoparticles (NPs). NPs are defined as materials having at least one dimension below $100 \mathrm{~nm}$. NPs have unique properties useful in many applications. The most important features include a large surface area per unit mass and the potential to generate surface modifications which alter their properties. As a result, NPs have enhanced chemical reactivity, improved cell penetration and specific influences on biological systems. Moreover, the surface of NPs can be modified with various chemical groups which allow them to be conjugated to ligands or drugs $[23,90,120]$. As a result of their enhanced reactivity, NPs may generate toxic effects which differ from the bulk materials from which they are produced.

The number of NP-based applications is significantly increasing, and many products containing NPs are commercially available. There is great excitement about the potential benefits of NPs in medical applications. NPs have been tested as vehicles for gene therapy and drug delivery and as tools in diagnostic imaging and targeting systems for recognition of cancer cells [90]. Metal NPs in general and silver nanoparticles (AgNPs) in particular are among the

Table I. Selected medical applications of silver nanoparticles

\begin{tabular}{|lc|}
\hline Medical applications & References \\
\hline Bone prostheses & {$[17]$} \\
\hline Contraceptive devices & {$[91]$} \\
\hline Gloves & {$[58]$} \\
\hline Medical catheters & {$[117]$} \\
\hline Orthopedic implants & {$[110]$} \\
\hline Prosthetic devices & {$[21]$} \\
\hline Endotracheal tubes & {$[83]$} \\
\hline Surgical instruments & {$[31]$} \\
\hline Wound dressings & {$[142]$} \\
\hline $\begin{array}{l}\text { Dental restorative materials, endodontic } \\
\text { cements, dental implants }\end{array}$ & {$[43]$} \\
\hline
\end{tabular}

most important nanomaterials used in a wide range of industrial applications. According to the Woodrow Wilson inventory, about $30 \%$ of all NP-based products in the marketplace contain AgNPs [114]. The list of AgNP-based consumer products includes cleansers for disinfecting hard surfaces, laundry and dishwashing detergents, bath and sports towels, clothing, socks, underwear, water and air filters, personal cleansers, deodorants, cosmetics, cleansing soaps, toothbrushes, toothpastes, health supplements, nursing bottles and associated nipples, children's toys, and nanosilver-coated devices such as mobile phones and laptops. Appliances such as refrigerators and washing machines include interior coatings with AgNPs. Additionally, silver nanoparticles are included in paints used to cover walls in hospital rooms and in food storage containers (a complete listing of AgNP-based products is available at: $h t t p: / / w w w$. nanotechproject.org/process/assets/files/7039/ silver_database_fauss_sept2_final.pdff). The medical applications of AgNPs are summarized in Table I.

This particular interest in AgNPs relates to their antimicrobial activity. The rapid development of bacterial resistance against conventional antimicrobials and the challenges involved in development of new drugs have led to searches for promising alternatives. The smallest AgNPs, which have sizes within a range of a few nanometers, exhibit particularly strong antibacterial effects $[61,82,94]$. It has been found that in addition to size, the specific types of surface-coating agents have a significant effect on the biocidal potency of AgNPs [27]. AgNPs are also effective against fungi and viruses $[40,42]$.

Although the commercialization of AgNPs has led to great excitement about potential benefits of their strong antimicrobial activity, it has simultaneously created a risk of hazardous interactions with biological systems $[69,76]$.

There is a potential hazard to the environment and human health when AgNPs present in commercially available products, such as clothing, towels, socks, underwear, and toys, are released to the environment when these items are washed. AgNPs present in personal care products, cleaning supplies, detergents or cosmetics can be directly introduced into the environment during use and/or disposal [10,11]. Applications such as health supplements containing AgNPs, as well as food and drink storage containers, may also be a source of AgNPs [24]. Moreover, increasing 
use of silver nanoparticles is expected to raise occupational exposure mainly through inhalation [18].

AgNPs released from consumer products are expected to enter aquatic and terrestrial ecosystems, but their fate after long-term accumulation and their impact on the environment are not fully known. There is significant concern regarding aquatic organisms in locations where AgNPs accumulate $[87,115,140]$. Unfortunately, our knowledge about the environmental and human risks remains at a very low level. It is therefore challenging to assess the long-term health consequences of environmental contamination. This problem is currently in the center of interest for scientists and various national agencies as well as public and private organizations.

\section{Routes of exposure and biodistribution of AgNPs in mammalian organisms}

Since AgNPs are found in a wide variety of products, exposure to them may occur via different routes of entry into the body. AgNPs from consumer products or medical applications may gain access to systemic circulation via oral or intravenous exposure as well as via inhalation or through the skin.

The gastrointestinal tract is the most likely route of entry for silver nanoparticles, directly through intentional ingestion (medical or dietary supplements, toothpastes) or indirectly via dissolution of AgNPs from products (food and drink containers, toothbrushes) [24]. Moreover, increasing environmental contamination may further lead to indirect and unintentional ingestion via consumption of water or fish. Inhalation of dust and fumes containing AgNPs or skin contact occurs mainly in occupational settings. Furthermore, certain products such as cosmetics, clothing, underwear, socks or wound dressings may allow AgNPs to penetrate the skin, primarily under conditions of concomitant presence of skin diseases such as allergic dermatitis, atopic eczema, psoriasis or simply during skin damage [92]. Medical or diagnostic compounds can also cause entry of AgNPs into the circulatory system by intravenous administration.

Information about absorption of AgNPs is incomplete. Park and co-workers observed that the bioavailability of AgNPs $(7.9 \mathrm{~nm})$ after oral administration to rats was very low, in the range of $1.2 \%$ to $4.2 \%$ based on a single dose [101]. Following entry into the systemic circulation, AgNPs can become distributed among a number of mammalian organs, most notably liver and spleen $[73,145]$. Furthermore, silver nanoparticles have been found in blood, lungs, kidney, brain, heart and genital organs $[67,70,73,81,101,131,145]$. The results of research on the biodistribution of AgNPs indicate that most organs are able to remove AgNPs over time, with the exception of brain and testes $[70,138]$. Numerous studies have shown that AgNPs can be distributed within the brain of mammals, regardless of the route of exposure. Selected studies on biodistribution of AgNPs in mammalian brain are listed in Table II.

Lee and co-workers observed that after a single intravenous injection of citrate-coated AgNPs $(7.9 \mathrm{~nm})$, they become distributed in serum, liver, kidney, spleen, lungs, brain, testes and thymus of rabbits. Significantly, the presence of silver nanoparticles was observed at time points 1,7 and 28 days after the injection [73]. Silver was also detected in brain of rats at 24, 96 and $168 \mathrm{~h}$ after an intraperitoneal injection of bovine serum albumin-coated $2 \mathrm{~nm}$ AgNPs [45].

Studies using the model of oral exposure to nanosilver indicate distribution among many organs of animals, including brain, after 90 days of repeated administration [67]. In organs of rats chronically exposed to AgNPs $(10,25 \mathrm{~nm}$ ) by the oral route, nano-sized granules were observed in liver, kidney, spleen, brain, testes and ovaries [70]. Moreover, the oral exposure of rats to uncoated AgNPs (<20 nm) or PVP-coated AgNPs $(<15 \mathrm{~nm})$ showed a very similar pattern of biodistribution. The nano-sized granules were detected in liver, kidney, lungs, heart, spleen, brain, bladder, testes, blood, intestine and stomach [138]. Subchronic inhalation of AgNPs may also cause them to enter systemic circulation. Studies in which rats were exposed to AgNPs (18-19 nm) via inhalation for 13 weeks revealed that the lungs and liver are targeted organs. Additionally, nano-sized granules were identified in kidney, the olfactory bulb, blood and brain tissue [131]. The results of a study on the biodistribution of AgNPs (25 nm) after a single dose via intranasal administration demonstrated that silver accumulates in spleen, lungs, kidney, the nasal cavity and brain tissue [46].

Additionally, the assessment of the level of silver in urine and feces of treated animals suggests that excretion of AgNPs occurs mainly via feces, indicating that AgNPs are secreted in bile $[63,73,101]$. 
Table II. Studies on the biodistribution of AgNPs in mammalian organisms

\begin{tabular}{|c|c|c|c|c|c|}
\hline $\begin{array}{l}\text { Surface coatings } \\
\text { and/or sizes } \\
\text { of AgNPs }\end{array}$ & $\begin{array}{l}\text { Animal } \\
\text { model }\end{array}$ & $\begin{array}{c}\text { Route } \\
\text { of administration } \\
\text { and dosage }\end{array}$ & $\begin{array}{l}\text { Time of AgNP level } \\
\text { measurement after last } \\
\text { administration and time } \\
\text { of administration }\end{array}$ & $\begin{array}{l}\text { Organs/tissues } \\
\text { examined }\end{array}$ & References \\
\hline $\begin{array}{l}\text { AgNPs: } 20 \text { and } \\
200 \mathrm{~nm}\end{array}$ & Rats & i.v. $5 \mathrm{mg} / \mathrm{kg}$ b.w. & $\begin{array}{l}1,7 \text { and } 28 \text { days after } \\
\text { single injection }\end{array}$ & $\begin{array}{l}\text { Liver, spleen, kidney, } \\
\text { lungs and brain }\end{array}$ & [29] \\
\hline $\begin{array}{l}\text { Citrate-coated } \\
\text { AgNPs: } 7.9 \mathrm{~nm}\end{array}$ & Rabbits & i.v.: 0.5 or $5 \mathrm{mg} / \mathrm{kg}$ b.w. & $\begin{array}{l}1,7 \text { and } 28 \text { days after } \\
\text { single injection }\end{array}$ & $\begin{array}{l}\text { Serum, liver, kidney, } \\
\text { spleen, lungs, brain, } \\
\text { testes and thymus }\end{array}$ & [73] \\
\hline $\begin{array}{l}\text { BSA-coated } \\
\text { AgNPs: } 2 \mathrm{~nm}\end{array}$ & Rats & i.p.: $50 \mathrm{mg} / \mathrm{kg}$ b.w. & $\begin{array}{l}\text { 24, } 96 \text { and } 168 \mathrm{~h} \text { after } \\
\text { single injection }\end{array}$ & $\begin{array}{l}\text { Liver, spleen, kidney, } \\
\text { heart, lungs and brain }\end{array}$ & {$[45]$} \\
\hline $\begin{array}{l}\text { AgNPs: } \\
50-100 \mathrm{~nm}\end{array}$ & Rats & s.c.: $62.8 \mathrm{mg} / \mathrm{kg}$ b.w. & $\begin{array}{c}2,4,8,12,18 \text { and } 24 \text { weeks } \\
\text { after single injection }\end{array}$ & Brain & {$[135]$} \\
\hline AgNPs: $25 \mathrm{~nm}$ & Mice & $\begin{array}{c}\text { Intranasal: } \\
100 \text { or } 500 \mathrm{mg} / \mathrm{kg} \text { b.w. }\end{array}$ & $\begin{array}{l}1 \text { and } 7 \text { days after } \\
\text { single treatment }\end{array}$ & $\begin{array}{l}\text { Spleen, lungs, kidney, } \\
\text { nasal cavity and brain }\end{array}$ & [46] \\
\hline AgNPs: $56 \mathrm{~nm}$ & Rats & $\begin{array}{c}\text { Oral: } 30,125 \\
\text { or } 500 \mathrm{mg} / \mathrm{kg} \text { b.w./day }\end{array}$ & $\begin{array}{l}90 \text { days of repeated } \\
\text { exposure }\end{array}$ & $\begin{array}{l}\text { Blood, liver, kidney, lungs, } \\
\text { testes and brain }\end{array}$ & {$[67]$} \\
\hline $\begin{array}{l}\text { AgNPs: } \\
10 \text { and } 25 \mathrm{~nm}\end{array}$ & Rats & $\begin{array}{c}\text { Oral: } \\
100 \text { or } 500 \text { mg/kg b.w./ } \\
\text { day }\end{array}$ & $\begin{array}{l}28 \text { days of repeated expo- } \\
\text { sure with measurement of } \\
\text { silver level after a wash-out } \\
\text { period of } 1,2 \text { and } 4 \text { months }\end{array}$ & $\begin{array}{l}\text { Blood, brain, kidney, } \\
\text { spleen, liver, testes } \\
\text { and ovaries }\end{array}$ & [70] \\
\hline $\begin{array}{l}\text { PVP-coated } \\
\text { AgNPs: } 14 \pm 4 \mathrm{~nm}\end{array}$ & Rats & Oral: 9 mg/kg b.w./day & $\begin{array}{l}28 \text { days of repeated } \\
\text { exposure }\end{array}$ & $\begin{array}{l}\text { Plasma, liver, kidney, } \\
\text { stomach, lungs, muscle, } \\
\text { brain and small intestine }\end{array}$ & {$[81]$} \\
\hline $\begin{array}{l}\text { AgNPs: } 22,42 \\
\text { and } 71 \mathrm{~nm}\end{array}$ & Mice & Oral: 1 mg/kg b.w./day & $\begin{array}{l}14 \text { days of repeated } \\
\text { exposure }\end{array}$ & $\begin{array}{l}\text { Liver, kidney, brain, } \\
\text { lungs and testes }\end{array}$ & [99] \\
\hline $\begin{array}{l}\text { Uncoated AgNPs: } \\
<20 \mathrm{~nm}, \\
\text { PVP-coated } \\
\text { AgNPs: <15 nm }\end{array}$ & Rats & $\begin{array}{c}\text { Oral: } 90 \mathrm{mg} / \mathrm{kg} \text { b.w./ } \\
\text { day }\end{array}$ & $\begin{array}{l}28 \text { days of repeated expo- } \\
\text { sure; the measurement of } \\
\text { silver level } 1 \text { day, } 1 \text { week } \\
\text { and } 8 \text { weeks after previous } \\
\text { administration }\end{array}$ & $\begin{array}{l}\text { Liver, kidney, lungs, } \\
\text { heart, spleen, brain, } \\
\text { bladder, testes, blood, } \\
\text { intestine and stomach }\end{array}$ & [138] \\
\hline AgNPs: $18-19$ nm & Rats & $\begin{array}{c}\text { Inhalation: 49, } 133 \text { or } \\
515 \text { mg AgNPs/m(3) }\end{array}$ & $\begin{array}{c}\text { Exposure for } 6 \text { h/day, } \\
5 \text { days/week, for } 13 \text { weeks } \\
\text { in a whole-body inhalation } \\
\text { chamber }\end{array}$ & $\begin{array}{l}\text { Liver, kidney, olfactory } \\
\text { bulb, brain, lungs, } \\
\text { and blood }\end{array}$ & [131] \\
\hline
\end{tabular}

AgNPs - silver nanoparticles, BSA - bovine serum albumin, PVP - polyvinylpyrrolidone, i.v. - intravenous, i.p. - intraperitoneal, s.c. - subcutaneous, b.w. - body weight

\section{Toxicity of AgNPs}

There has been significant progress in silverbased nanotechnology in recent years. The commercialization of nanoproducts is increasing each year, and studies on the toxicological potential of such products are needed. Currently available information about hazards associated with AgNPs requires further verification.

The existing data suggest that the size of AgNPs is highly correlated with their toxicity. In many studies with mammalian cells, it was found that smaller AgNPs are more toxic than larger ones in equivalent dosages. The role of the size of AgNPs in toxicity was confirmed in in vitro experiments comparing cytotoxicity and genotoxicity of 20, 80 and $113 \mathrm{~nm}$ AgNPs [102]. Furthermore, cytotoxic effects were exhibited by $10 \mathrm{~nm}$ AgNPs, but not 40 and $75 \mathrm{~nm}$ citrate-coated silver nanoparticles [48]. Size-dependent toxicity of AgNPs was also confirmed in studies on the influence of 15, 30 and $55 \mathrm{~nm}$ AgNPs on viability and oxidative stress induction in alveolar macrophages [15]. Research was also designed to evaluate size-dependent cytotoxic effects of AgNPs of different sizes (5, 20 and $50 \mathrm{~nm}$ ) on various types of human cells. In all toxicity endpoint studies (cell morphology, viability, cellular membrane integrity and oxidative stress) it was observed that $5 \mathrm{~nm}$ AgNPs induce the most severe damage, with larger particles inducing less damage [78]. 
The surfaces of silver nanoparticles are often coated with various types of compounds to provide stability and prevent agglomeration. For example, polysaccharide-coated AgNPs do not agglomerate, in contrast to uncoated AgNPs [1]. The type of capping agent may also play a crucial role in stabilization of AgNPs. Polyvinylpyrrolidone (PVP)-coated AgNPs were found to be stable over a 1-week period in water, whereas citrate-coated AgNPs are unstable [136].

The most popular types of nanoparticle coatings are citrate, chitosan, PVP, polysaccharides, peptides and carbon. Different types of superficial agents may generate coating-specific behavior of AgNPs in solution [66] or in physiological fluids [13], and consequently may cause different antimicrobial or toxic effects.

Only a few studies have compared the influence of various coating agents on AgNP-induced toxicity; therefore this issue is still not fully understood. Among other effects, it was demonstrated that carbon-coated silver nanoparticles influence cell viability to a lesser extent than uncoated AgNPs of similar size [95], whereas polysaccharide-coated AgNPs cause more severe effects than uncoated AgNPs [1]. Moreover, it was shown that PVP-coated [66] or peptide-coated [51] AgNPs are more toxic than citrate-coated AgNPs with similar particle core sizes.

It is also claimed that all observed AgNP-mediated toxic effects are a consequence of silver ions released from the surface of nanoparticles inside cells through the "Trojan Horse effect" $[48,100,126]$. Moreover, it is considered that smaller AgNPs are able to release silver ions from their surfaces more efficiently than larger ones, because of the larger surface area per unit mass [48].

$\mathrm{Ag}^{+}$ions are released after surface oxidation of AgNPs. Notably, it was shown that the intracellular solubility of AgNPs is 50 times greater than their solubility in pure water [126].

The most effective cellular conditions for dissolving endocytosed AgNPs are found in the acidic environment of lysosomes, which has a pH of about 4.8 $[26,122]$. However, it has been suggested that the toxic effects are a combined result of both AgNPs and released silver ions $[16,44,108,127]$.

It was observed that PVP-coated AgNPs and $\mathrm{Ag}^{+}$ ions both affect cellular pathways involved in oxidative stress and homeostasis of $\mathrm{Na}^{+}, \mathrm{K}^{+}$and $\mathrm{H}^{+}$ ions. Toxic effects of AgNPs on fish were found to be mediated by activation of a few nuclear recep- tors and inhibition of ligand binding to the dopamine receptor. In contrast, in tissues of $\mathrm{Ag}^{+}$-exposed fish, ligand binding to adrenergic receptors $\alpha 1$ and $\alpha 2$ and cannabinoid receptor CB1 were found to be inhibited [44]. Powers and co-workers showed that ascorbate protects cells against $\mathrm{Ag}^{+}$-induced oxidative stress, but does not act as an effective antioxidant with respect to stress induced by AgNPs [108].

Other studies indicate that the pattern of expression of stress-related genes in liver of AgNP- or $\mathrm{Ag}^{+}$-treated fish (Japanese Medaka) is different [16]. Silver ions induce an inflammatory response in the liver of exposed fish, whereas AgNPs increase expression of genes implicated in DNA damage, carcinogenesis and oxidative stress.

\section{Toxic effects of AgNPs in microorganisms}

It was observed in a variety of studies that AgNPs exhibit antimicrobial activity against gram-positive (Staphylococcus aureus) and gram-negative bacteria (Pseudomonas aeruginosa and Escherichia coli) $[94,129,133]$. Thus it was proposed that AgNPs may constitute an attractive alternative to antibiotics. It has been proposed that silver nanoparticles could play a major role in solving the serious public health problem caused by the presence of multidrug-resistant bacteria, which are resistant to most antibiotics [4]. In addition, AgNPs are also useful in disrupting the formation of bacterial biofilms, wherein bacteria aggregate into complex invasive structures. These structures provide the basis for a natural survival strategy used by microorganisms after invasion of a host and provides resistance to a lot of commonly used anti-microbial agents. Strains of Pseudomonas aeruginosa and Staphylococcus epidermidis have been found to be susceptible to the anti-biofilm properties of AgNPs [65,98].

Even though the antibacterial effects of AgNPs have been extensively examined, their mechanisms of action have been only partially elucidated. Although one hypothesis emphasizes the role of silver ions released from the surfaces of AgNPs inside bacterial cells [53,82], direct action of AgNPs on microorganisms has also been proposed [64].

Many studies indicate that $\mathrm{AgNPs}$ or $\mathrm{Ag}^{+}$released from their surfaces may directly damage the cell membranes. Silver structures are known to adhere to the microbial cell wall and cause structural changes in the cell membrane proteins, such as cis-trans 
isomerization of unsaturated fatty acids. The chang es in the membrane components lead to increased membrane fluidity and decreased resistance to environmental factors [53]. Structural changes in membrane proteins cause them to become inactivated and released, causing degradation of membrane structure [129]. These abnormalities lead to a significant increase in permeability, resulting in cell death.

Structural proteins and enzymes with thiol groups are highly sensitive to inactivation by AgNPs or released $\mathrm{Ag}^{+}$ions [125]. Interactions of AgNPs with the thiol groups of the L-cysteine residue have been found to disturb the function of several enzymes of Staphylococcus epidermidis [50]. Moreover, both forms of silver may interact with bacterial DNA and prevent DNA replication and cell division, leading to cell death $[34,125]$. Another mechanism of antibacterial action induced by AgNPs is generation of reactive oxygen species, which damage all components of the cell, including cell membranes and DNA $[64,72]$.

The biocidal potency of AgNPs is also effective with respect to fungi and viruses. Antifungal activity against Cladosporium cladosporioides, Aspergillus niger [109], Trichophyton rubrum [104] and Candida sp. [93] has been demonstrated. AgNPs have been found to be a potential weapon against a wide range of viruses. Due to the low likelihood of resistance, AgNPs may provide effective antiviral therapies against HIV-1 [68], hepatitis B virus [84], herpes simplex virus types 1 [9] and 2 [97] and influenza virus [143]. The mechanism of antiviral potential of AgNPs is still being investigated. It is thought that AgNPs interact with glycoprotein receptors [68], the viral envelope [143] and double-stranded DNA/RNA [84], thereby preventing the replication of viruses, or block the binding of viruses to the host cell.

\section{Toxic effects of silver nanoparticles in mammals}

Following entry of AgNPs into the systemic circulation, they may migrate into many organs and induce toxicity. Table III lists studies demonstrating the negative influence of AgNPs in mammalian organisms. A series of studies has shown that systematically administered AgNPs cause inflammatory and cytotoxic effects including pulmonary toxicity after prolonged inhalation [132] and hepatotoxicity after prolonged oral [30,67,103], intravenous [25] or intraperitoneal [32] administration. Moreover, histo- pathological changes in kidneys and increasing levels of creatinine have been reported $[33,119]$, indicating that AgNPs may cause nephrotoxic effects. Impairment of spermatogenesis in rats exposed to AgNPs was also observed [128].

Toxic effects of AgNPs in liver of rodents have been intensively investigated. Adverse effects were observed including marked pathological changes in liver morphology $[32,67,71]$, changes in liver enzyme activities $[2,56,99]$, changes in the level of plasma lipids [30,67], generation of $\operatorname{ROS}[30,103]$ and inflammatory response $[25,99]$. Autophagy and apoptosis have been confirmed to play roles in mediating hepatotoxicity [71].

\section{Mechanisms of AgNP-induced toxicity}

In recent years, the mechanisms of AgNP-induced toxicity have been intensively investigated. It remains unknown if observed toxic effects are caused only by direct interaction of AgNPs with biological systems, or if silver ions released from the surfaces of the AgNPs inside the cell are also involved. In any case, the contribution of individual forms of silver has been found to induce toxicity, and a number of in vitro and in vivo studies have provided strong evidence for a connection between AgNP-mediated production of reactive oxygen species, oxidative stress, DNA damage, inflammation and cell death. A schematic representation of mechanisms of toxicity of AgNPs is shown in Figure 1.

It is likely that AgNP-mediated ROS production is related to physical (size, shape, surface charge) and chemical (surface coating, solubility, elemental composition) properties which create chemical conditions to induce an oxidative environment inside the cells. These conditions cause an imbalance in the cellular energy system, which depends on redox potential, leading to initiation of the inflammatory response or cell death. However, there is evidence that the mechanisms of toxicity of AgNPs towards neurons are much more complex [148].

\section{AgNP-induced oxidative stress and disruption of mitochondria}

Reactive oxygen species are chemically reactive molecules produced as natural byproducts during the mitochondrial electron transport process in aerobic respiration or by oxidoreductase enzymes and have an important role in cellular processes, such as 
Table III. Selected studies demonstrating toxic effects of silver nanoparticles in mammals

\begin{tabular}{|c|c|c|c|c|}
\hline $\begin{array}{l}\text { Type of } \\
\text { AgNPs }\end{array}$ & $\begin{array}{l}\text { Mammalian } \\
\text { model }\end{array}$ & $\begin{array}{l}\text { Administration } \\
\text { method, dosage, } \\
\text { time of exposure }\end{array}$ & Observed toxic effects & References \\
\hline $\begin{array}{l}\text { AgNPs: } \\
\text { 20, } 100 \mathrm{~nm}\end{array}$ & Rats & $\begin{array}{l}\text { i.v.: } 28 \text { days of repeated } \\
\text { administration, } \\
\text { dose } 6 \mathrm{mg} / \mathrm{kg} \text { b.w./day }\end{array}$ & $\begin{array}{l}\text { (Only } 20 \mathrm{~nm} \text { toxic) } \\
\text { - Decreased body weight } \\
\text { - Enlargement of spleen and liver } \\
\text { - Histopathological changes in liver, spleen and lymph } \\
\text { nodes } \\
\text { - Increased activity of liver enzymes (alkaline phos- } \\
\text { phatase, alanine transaminase and aspartate } \\
\text { transaminase) } \\
\text { - Changes in red blood cell parameters } \\
\text { - Changes in immune parameters (suppression of nat- } \\
\text { ural killer cells; changes in production of cytokines: } \\
\text { IL-10, IL-1 } 1 \beta \text {, IL-6, TNF- } \alpha \text {; decrease in interferon- } \gamma \text { pro- } \\
\text { duction; increase in IgM and IgE immunoglobulin } \\
\text { levels in serum) }\end{array}$ & {$[25]$} \\
\hline $\begin{array}{l}\text { AgNPs: } \\
20 \mathrm{~nm}\end{array}$ & Rats & $\begin{array}{l}\text { Oral: } 81 \text { days of repeated } \\
\text { administration, } \\
\text { dose } 500 \mathrm{mg} / \mathrm{kg} \text { b.w./day }\end{array}$ & $\begin{array}{l}\text { - Decreased body weight } \\
\text { - Increased level of total cholesterol and LDL-choles- } \\
\text { terol and decreased level of triglycerides } \\
\text { - Increased plasmatic alanine transaminase activity } \\
\text { - Increased liver and cardiac superoxide anion }\left(\mathrm{O}_{2}{ }^{\cdot-}\right) \\
\text { production } \\
\text { - Increased level of IL-6 and TNF- } \alpha \text { in liver } \\
\text { - No changes in liver SOD activity, liver lipid peroxida- } \\
\text { tion and plasma antioxidant capacity }\end{array}$ & [30] \\
\hline $\begin{array}{l}\text { AgNPs: } \\
56 \mathrm{~nm}\end{array}$ & Rats & $\begin{array}{l}\text { Oral: } 90 \text { days of repeated } \\
\text { administration, dose } 30 \text {, } \\
125 \text { or } 500 \mathrm{mg} / \mathrm{kg} \text { b.w./day }\end{array}$ & $\begin{array}{l}\text { - Decreased body weight of male rodents } \\
\text { - Increased alkaline phosphatase activity (dose } 500 \mathrm{mg} / \\
\text { kg b.w.) } \\
\text { - Increased level of cholesterol (doses: } 125 \text { and } 500 \mathrm{mg} / \\
\text { kg b.w.) } \\
\text { - Histopathological changes in liver tissues (bile-duct } \\
\text { hyperplasia, fibrosis, pigmentation inflammatory } \\
\text { cell infiltration) and intestines (pigmentation) } \\
\text { - No changes in hematological parameters, except for } \\
\text { a significant increase in the number of monocytes } \\
\text { (dose } 500 \mathrm{mg} / \mathrm{kg} \text { b.w.) }\end{array}$ & [67] \\
\hline $\begin{array}{l}\text { AgNPs: } \\
10-30 \mathrm{~nm}\end{array}$ & Rats & $\begin{array}{c}\text { i.p.: single injection, } \\
\text { dose } 500 \mathrm{mg} / \mathrm{kg} \text { b.w./day }\end{array}$ & $\begin{array}{l}\text { - Low level of ATP content in liver tissue } \\
\text { - Induction of autophagy and apoptosis in liver } \\
\text { - Histopathological changes in liver tissues (piecemeal } \\
\text { necrosis and chronic inflammatory cell infiltration) }\end{array}$ & [71] \\
\hline $\begin{array}{l}\text { AgNPs: } \\
22,42 \\
\text { and } 71 \mathrm{~nm}\end{array}$ & Mice & $\begin{array}{l}\text { Oral: } 14 \text { days of repeated } \\
\text { administration, } \\
\text { dose } 1 \mathrm{mg} / \mathrm{kg} \text { b.w./day } \\
\text { or } 28 \text { days of repeated } \\
\text { administration, } \\
\text { dose } 1 \mathrm{mg} / \mathrm{kg} \text { b.w./day } \\
(42 \mathrm{~nm})\end{array}$ & $\begin{array}{l}\text { - No changes in body weight of rodents } \\
\text { - Increased level of TGF- } \beta \text { in serum after } 14 \text { days of } \\
\text { administration (other cytokines not investigated) } \\
\text { - Increased level of cytokines: IL-1, IL-6, IL-4, IL-10, } \\
\text { IL-12 and TGF- } \beta \text { in serum after } 28 \text { days of exposure } \\
\text { - Increased distribution of NK cells and B cells after } \\
14 \text { and } 28 \text { days } \\
\text { - Increased activity of liver enzymes (alkaline phos- } \\
\text { phatase, alanine transaminase and aspartate trans- } \\
\text { aminase) } \\
\text { - Increased IgE production after } 28 \text { days of adminis- } \\
\text { tration } \\
\text { - No histopathological changes in organs (liver, kidney } \\
\text { and small intestine) }\end{array}$ & [99] \\
\hline
\end{tabular}


Table III. Cont.

\begin{tabular}{|c|c|c|c|c|}
\hline $\begin{array}{l}\text { Type of } \\
\text { AgNPs }\end{array}$ & $\begin{array}{l}\text { Mammalian } \\
\text { model }\end{array}$ & $\begin{array}{l}\text { Administration } \\
\text { method, dosage, } \\
\text { time of exposure }\end{array}$ & Observed toxic effects & References \\
\hline $\begin{array}{l}\text { AgNPs: } \\
10 \mathrm{~nm}\end{array}$ & Rats & $\begin{array}{c}\text { Oral: } 5 \text { days of repeated } \\
\text { administration at doses } \\
\text { of: } 5,25,50 \\
\text { and } 100 \mathrm{mg} / \mathrm{kg} \text { b.w./day }\end{array}$ & $\begin{array}{l}\text { (Effects observed for doses of } 50 \text { and } 100 \mathrm{mg} / \mathrm{kg} \text { b.w.) } \\
\text { - Induction of ROS production in liver } \\
\text { - Increased activity of liver enzymes (alkaline phos- } \\
\text { phatase, alanine transaminase and aspartate trans- } \\
\text { aminase) } \\
\text { - Increased lipid peroxidation in liver tissue } \\
\text { - Morphological alterations in liver tissue (hepatocyte } \\
\text { disruption, hepatocellular vacuolization, degenera- } \\
\text { tion of liver, central vein injury and areas of necrosis) } \\
\text { - DNA damage in liver }\end{array}$ & [103] \\
\hline $\begin{array}{l}\text { AgNPs: } \\
\text { size } \\
<100 \mathrm{~nm}\end{array}$ & Rats & $\begin{array}{l}\text { i.p.: two injections of } \\
\text { AgNPs in a dose } \\
\text { of } 2 \mathrm{mg} / \mathrm{kg} \text { b.w./day }\end{array}$ & $\begin{array}{l}\text { - Histopathological alterations in liver and renal tis- } \\
\text { sues } \\
\text { - Increased number of white blood cells and increased } \\
\text { hemoglobin level } \\
\text { - Increased serum creatinine, urea, and aspartate and } \\
\text { alanine aminotransferases }\end{array}$ & [119] \\
\hline $\begin{array}{l}\text { AgNPs: } \\
18 \mathrm{~nm}\end{array}$ & Rats & $\begin{array}{l}90 \text { days of } 6 \mathrm{~h} / \text { day } \\
\text { exposure via inhalation } \\
\text { at concentrations of } \\
0.7 \times 10^{6}, 1.4 \times 10^{6} \text { and } \\
2.9 \times 10^{6} \text { particles } / \mathrm{cm}^{3}\end{array}$ & $\begin{array}{l}\text { - Significant decrease of tidal volume and minute vol- } \\
\text { ume } \\
\text { - Histopathological changes in lungs (mixed inflam- } \\
\text { matory cell infiltration, chronic alveolar inflamma- } \\
\text { tion and small granulomatous lesions) }\end{array}$ & [132] \\
\hline $\begin{array}{l}\text { AgNPs: } \\
8.7 \mathrm{~nm}\end{array}$ & Rats & $\begin{array}{c}\text { i.p.: } 28 \text { days of repeated } \\
\text { administration at doses } \\
\text { of } 1,2 \text {, and } 4 \mathrm{mg} / \\
\mathrm{kg} \text { b.w./day }\end{array}$ & $\begin{array}{l}\text { - No significant changes in the body weight of rodents } \\
\text { - Histopathological changes in liver tissue (bile-duct } \\
\text { hyperplasia, cholangiofibrosis, hepatocellular necro- } \\
\text { sis and leukocytosis) } \\
\text { - Increased lipid peroxidation in liver tissue after dose } \\
\text { of } 2 \text { and } 4 \mathrm{mg} / \mathrm{kg} \text { b.w. } \\
\text { - No change in GSH level in liver tissue } \\
\text { - Chromosomal aberrations after } 4 \mathrm{mg} / \mathrm{kg} \text { b.w. }\end{array}$ & {$[32]$} \\
\hline $\begin{array}{l}\text { AgNPs: } \\
35-45 \mathrm{~nm}\end{array}$ & Mice & $\begin{array}{l}\text { Oral: } 14 \text { days of repeated } \\
\text { administration at a dose } \\
\text { of } 50 \mu \text { l of AgNP solution } \\
\text { at concentration } \\
\text { of } 20 \text { or } 50 \text { ppm }\end{array}$ & $\begin{array}{l}\text { - Increased activity of liver enzymes (alanine transam- } \\
\text { inase and aspartate transaminase) } \\
\text { - No change in blood parameters (values of red blood } \\
\text { cells, hemoglobin and hematocrit) } \\
\text { - Histopathological changes in liver (cytoplasmic vac- } \\
\text { uolization of hepatocytes with necrosis, inflamma- } \\
\text { tion and degeneration of hepatic cells) }\end{array}$ & {$[56]$} \\
\hline $\begin{array}{l}\text { AgNPs: } \\
21 \pm 8 \mathrm{~nm}\end{array}$ & Rats & $\begin{array}{l}\text { i.v.: single injection, } \\
\text { dose } 10 \mathrm{mg} / \mathrm{kg} \text { b.w.; } \\
\text { intratympanic injection: } \\
40 \mu \mathrm{l} \text { of } 0.4 \% \text { of } \mathrm{AgNP} \\
\text { was injected into the } \\
\text { middle ear cavity }\end{array}$ & $\begin{array}{l}\text { - Glycosaminoglycan accumulation in the basement } \\
\text { membrane associated with up-regulation of pro- } \\
\text { duction of hyaluronic acid in kidney and cochlea } \\
\text { (after i.v. injection) leading to renal failure and } \\
\text { hearing loss (a significant hearing loss over a broad } \\
\text { range of frequencies after intratympanic injection) } \\
\text { - Increased concentration of urea and creatinine in } \\
\text { the serum (after i.v. injection) } \\
\text { - Presence of proteins in the urine (after i.v. injection) }\end{array}$ & [33] \\
\hline
\end{tabular}


Table III. Cont.

\begin{tabular}{|c|c|c|c|c|}
\hline $\begin{array}{l}\text { Type of } \\
\text { AgNPs }\end{array}$ & $\begin{array}{l}\text { Mammalian } \\
\text { model }\end{array}$ & $\begin{array}{l}\text { Administration } \\
\text { method, dosage, } \\
\text { time of exposure }\end{array}$ & Observed toxic effects & References \\
\hline $\begin{array}{l}\text { AgNPs: } \\
43.6 \\
\pm 6.4 \mathrm{~nm}\end{array}$ & Mice & $\begin{array}{l}\text { i.p.: single injection in } \\
\text { doses of } 26,52 \text { and } \\
78 \mathrm{mg} / \mathrm{kg} \text { b.w.; animals } \\
\text { were sacrificed } 24 \text { and } \\
72 \mathrm{~h} \text { after injection }\end{array}$ & $\begin{array}{l}\text { - Increased activity of liver enzymes (alkaline phos- } \\
\text { phatase, alanine transaminase and aspartate } \\
\text { transaminase) - } 24 \text { and } 72 \mathrm{~h} \text { after injection in all } \\
\text { doses } \\
\text { - Oxidative DNA damage in lymphocytes - } 24 \text { and } \\
72 \mathrm{~h} \text { after injection in all doses } \\
\text { - Induction of apoptosis in liver tissue - mainly after } \\
78 \text { mg AgNPs/kg b.w.) } \\
\text { - Histopathological changes in liver (lymphocyte infil- } \\
\text { tration in the hepatic portal space, necrosis, vacuoli- } \\
\text { zation of hepatocytes and edema around the blood } \\
\text { vessels) }\end{array}$ & [2] \\
\hline $\begin{array}{l}\text { AgNPs: } \\
20 \mathrm{~nm}\end{array}$ & Rats & $\begin{array}{c}\text { i.v.: } 28 \text { days of repeated } \\
\text { administration at doses } \\
\text { of } 0.0082,0.025,0.074 \\
0.22,0.67,2, \\
\text { and } 6 \mathrm{mg} / \mathrm{kg} \text { b.w. }\end{array}$ & $\begin{array}{l}\text { - Decreased body weight } \\
\text { - Reduced thymus weight and increased spleen } \\
\text { weight, no effect on liver and kidney weights } \\
\text { - Decrease of NK cell activity } \\
\text { - Changes in red blood cell, hemoglobin and white } \\
\text { blood cell parameters } \\
\text { - Decreased IgG and increased IgM levels } \\
\text { - Changes in the level of cytokines }\end{array}$ & [139] \\
\hline $\begin{array}{l}\text { AgNPs: } \\
20 \mathrm{~nm}\end{array}$ & Rats & $\begin{array}{l}\text { i.v.: single injection, dose: } \\
238-263 \mu \mathrm{g} / \mathrm{kg} \text { b.w. }\end{array}$ & $\begin{array}{l}\text { - No changes in GSH level in liver } \\
\text { - Increased mRNA expression of IL-8, macrophage } \\
\text { inflammatory protein 2, IL-1 receptor and TNF- } \alpha \text {; } \\
\text { and no changes in mRNA level of IL-1 } \beta \text {, IL-10 }\end{array}$ & [39] \\
\hline
\end{tabular}

growth, proliferation, apoptosis, differentiation and activation of cell signaling cascades [55]. Moreover, phagocytic cells are able to produce ROS while participating in induction of host cell defense mechanisms [111,121].

ROS are generated mainly in mitochondria during oxidative phosphorylation. Physiologically, cells defend themselves against ROS damage with antioxidant enzymes such as superoxide dismutase (SOD), catalase, glutathione peroxidase (GPx) and glutathione S-transferase, as well as using non-enzymatic factors such as glutathione to reduce ROS. An imbalance between the level of destructive ROS and the availability of biological systems for detoxification of the reactive species leads to oxidative stress [12]. Pathologically increased free radicals cause oxidative damage to all cell components, including oxidation of polyunsaturated fatty acids in lipids, oxidation of amino acids in proteins and DNA damage. Significant damage to cell structures leads to apoptotic cell death if cellular repair mechanisms are ineffective [37]. Brain tissues are highly sensitive to abnormal levels of ROS, because their defensive mechanisms are limited. Moreover, reactive oxygen species are involved in the development of the inflammatory response, which is an important element of the pathogenesis of neurodegenerative diseases such as Alzheimer's disease [107] or Parkinson's disease [41].

Presumably, AgNP-mediated ROS production is associated with intracellular oxidation of AgNPs to $\mathrm{Ag}^{+}$ions. This chemical process creates a pro-oxidant environment which interferes with mitochondrial functions and may lead to overproduction of ROS and mitochondrial damage [126]. A deleterious influence of silver on mitochondrial functions has been observed in vitro in rat liver cells [60], human liver cells $[106,130]$ and human colon cancer cells [118]. Moreover, AgNPs were shown to decrease the activity of mitochondrial respiratory chain complexes I, II, III and IV, leading to a drop in ATP levels and increased rates of ROS production [7,22].

Furthermore, it has also been proposed that AgNPs may interact, directly or via released $\mathrm{Ag}^{+}$ions, with amino acid thiol groups, disrupting the function of structural proteins in mitochondrial membranes 


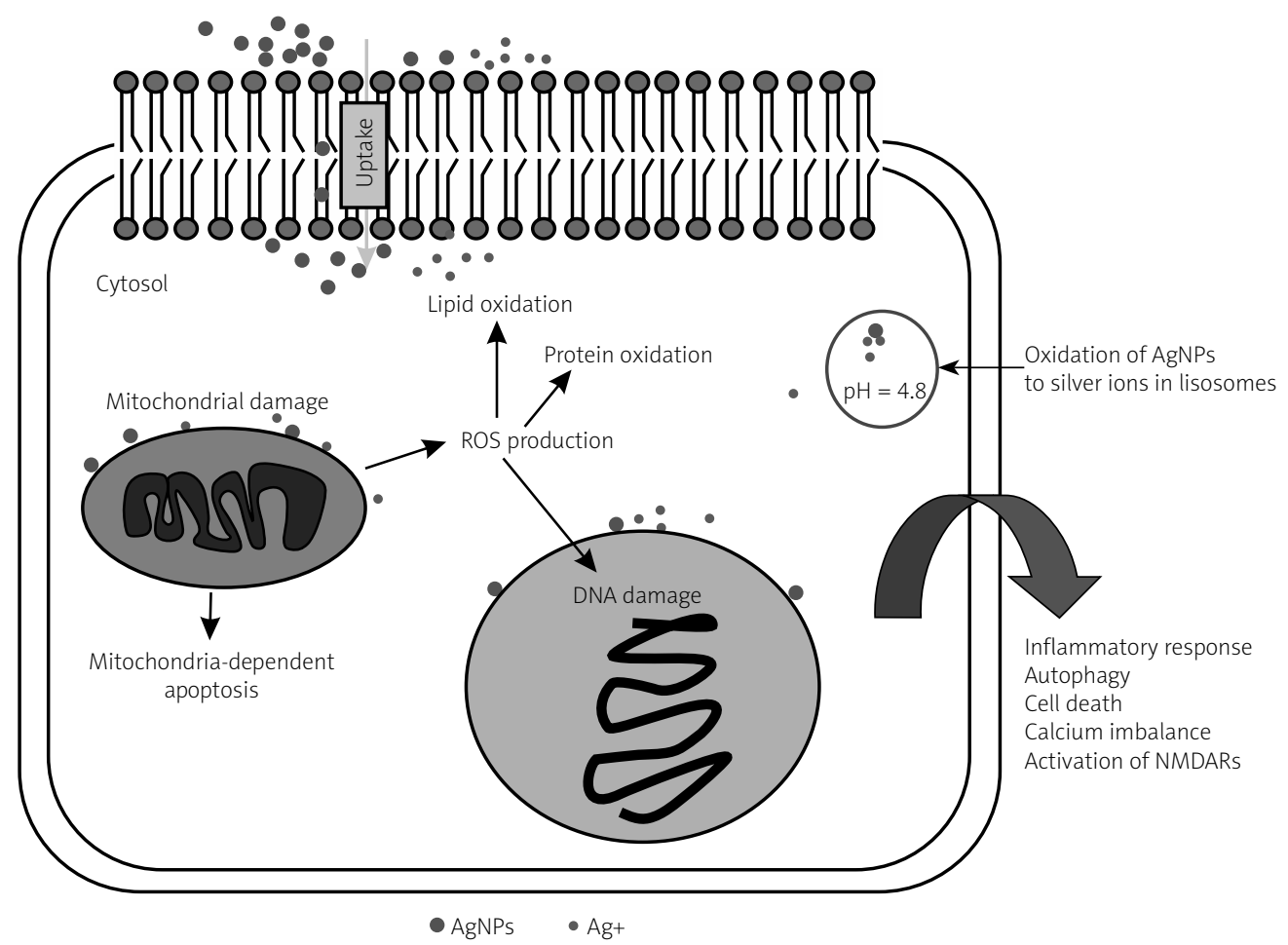

Fig. 1. Schematic representation of the mechanisms of AgNPs toxicity.

and/or mitochondrial enzymes [62]. For example, $\mathrm{Ag}^{+}$ ions were observed to interfere with thiol groups in the mitochondrial inner membrane, increasing its permeability [5]. This mechanism of AgNPs toxicity may be confirmed by the fact that weak antioxidants with -SH groups such as 2,3-dithiopropanol [26], $\mathrm{N}$-acetylcysteine (NAC) [62], methionine and cysteine are more effective against AgNP-induced cytotoxicity than the most potent antioxidants without thiol groups such as Trolox (water soluble vitamin E analog) or Tempol [126].

Overproduction of ROS during exposure to AgNPs has been proven directly in several in vitro investigations $[15,26,78,141]$ and also in vivo $[30,103]$. Among the oxidative stress-related changes caused by AgNPs, depletion of reduced glutathione (GSH) has been observed in human skin carcinoma cells [6], rat liver cells [60], mouse macrophage cells [100], human liver cells $[106,141]$ and mouse embryonic fibroblasts [74]. Results of studies on aquatic organisms strongly support these in vitro observations $[3,38,86]$, whereas limited in vivo studies demonstrate a lack of changes in GSH levels in liver of exposed rodents $[32,39]$.
Furthermore, oxidative stress-related lipid peroxidation was demonstrated in vitro $[6,106]$ and in vivo in liver of exposed rats [32,103]. DNA damage induced by ROS has been detected in vitro as increased DNA fragmentation in human alveolar cells [35], human liver cells [106], human epithelial embryonic cells [116], and in vivo in rodents [2,32,103] and aquatic organisms exposed to AgNPs $[3,38]$.

Moreover, changes in the activity of antioxidant enzymes have been suggested to occur under the influence of AgNPs. Both decreased $[6,130]$ and increased [141] SOD activity has been observed. It was also found that exposure to AgNPs leads to a decrease in the activity levels of glutathione peroxidases in a human liver cell line [130].

\section{AgNP-induced inflammation and cell death}

Several in vitro studies provide evidence of an inflammatory response in cells exposed to AgNPs. The connection between increased ROS levels and the release of inflammatory mediators such as interleukin-6, tumor necrosis factor-alpha [95], interleukin-1 $\beta$ and macrophage inhibitory protein (MIP-2) in macro- 
phages [15] has been observed. The AgNP-mediated inflammatory response was also observed in rodent liver [30,56,67,71] and lungs [132], and increased expression of cytokines was observed in serum $[25,39,99]$.

As described above, AgNP-induced changes in the mitochondrial membrane potential disrupt mitochondria and lead to reduction of ATP content. This may activate the protective process of autophagy. This conservative intracellular protein degradation system promotes cell survival by allowing the use of misfolded proteins as well as injured and unnecessary cellular components as alternative energy sources. However, it has been shown that prolonged autophagy may induce cell death through excessive autolysis or apoptosis [47,89].

There have been limited studies demonstrating that AgNPs may induce autophagy. Correlations between decreasing ATP content, autophagy and apoptosis have been observed in liver of rats exposed to AgNPs [71]. Additionally, relationships between oxidative stress, autophagy and apoptosis have been demonstrated in mouse embryonic fibroblast cells [74]. Induction of apoptosis by AgNPs has been demonstrated in vitro in many types of mammalian cells, for example in THP-1 monocytes [36], human lung cancer cells [35], human liver cells [106], human colon cancer cells [118], fibroblast cells [57], mouse embryonic fibroblasts [74], HeLa cells (human cervical carcinoma), A549 cells (human lung carcinoma) [26], baby hamster kidney (BHK21) and human colon adenocarcinoma cells (HT29) [49]. It was suggested that exposure of cells to AgNPs promotes ROS- and JNK-dependent apoptotic pathways [57]. Activation of p53 [49], down-regulation of the anti-apoptotic protein $\mathrm{Bcl}-2$, up-regulation of pro-apoptotic protein Bax $[49,106]$, activation of caspase-3 $[49,74,106,118]$, release of cytochrome c from mitochondria into the cytosol, translocation of Bax to mitochondria $[57,106]$, formation of DNA adducts and DNA fragmentation $[26,35,36,118]$ have also been reported.

\section{Current evidence of AgNP-induced neurotoxicity}

The available data introduced in the section entitled "Routes of exposure and biodistribution of AgNPs in mammalian organisms" suggest that after entering bodily fluids, AgNPs can penetrate the brain tissues and be deposited there for long periods of time. There is a lack of information on the long-lasting effects of accumulation of AgNPs in brain parenchyma, and thorough studies on this subject are required. In this chapter we concentrate on the analysis of the side effects of AgNPs in cultured cells of cerebral origin and in brain tissue of exposed mammals.

Certain data demonstrate that AgNPs may enter the brain along the olfactory nerve when administered via inhalation or intranasally [46]. AgNPs may also penetrate the brain through the blood-brain barrier (BBB) during systemic or oral administration, as indicated in Table II. The evidence that AgNPs cause neurotoxic effects is demonstrated in Table IV.

\section{The influence of AgNPs on blood-brain barrier function}

The blood-brain barrier is a highly specialized brain endothelial structure which separates components of the circulating blood from brain parenchyma. The BBB is composed of a basement membrane and microvascular endothelial cells (BMVECs) which interact with pericytes, perivascular astrocytes and neurons. Transport of substances across the BBB is strictly regulated by both physical and metabolic barriers. The physical barrier is created by tight junctions between the BMVECs, whereas the metabolic barrier is provided by specialized enzymes and diverse transport systems [105]. It is quite likely that AgNPs influence the function of endothelial cells and increase the permeability of the BBB by direct toxic effects or by induction of a cascade of events leading to disruption of tight junctions. Since the tight junctions maintaining the integrity of the BBB have a gap of 4-6 $\mathrm{nm}$, it is very likely that nanoparticles pass through the endothelial cell membrane rather than through the inter-endothelial junctions. This is supported by the observation that endothelial cell membranes are undamaged [135].

It was demonstrated using an in vitro BBB model that AgNPs can pass the BBB mainly by transcytosis and accumulate inside endothelial cells of microvessels [134]. Moreover, there is evidence that AgNPs induce the release of IL-1 $\beta$ and TNF- $\alpha$ in rat brain microvessels and that this leads to inflammation and a subsequent increase in the permeability of the BBB [137].

The influence of silver nanoparticles on the BBB was also demonstrated in vivo. Tang and co-workers observed that subcutaneous injections of AgNPs (50-100 nm) to rats in a dose of $62.8 \mathrm{mg} / \mathrm{kg} \mathrm{b.w.}$ induce astrocyte swelling outside the blood-brain 
Table IV. Studies demonstrating neurotoxic effects of AgNPs in mammalian cells and mammals

\begin{tabular}{|c|c|c|c|c|}
\hline $\begin{array}{l}\text { Type of } \\
\text { AgNPs }\end{array}$ & $\begin{array}{l}\text { Mammals/ } \\
\text { Cell lines }\end{array}$ & $\begin{array}{c}\text { Time of exposure, } \\
\text { dose }\end{array}$ & Observed neurotoxic effects & References \\
\hline \multicolumn{5}{|l|}{ In vitro studies } \\
\hline $\begin{array}{l}\text { AgNPs: } 32.74- \\
380.25 \mathrm{~nm}\end{array}$ & $\begin{array}{l}\text { Rat } \\
\text { hippocam- } \\
\text { pal slices }\end{array}$ & $\begin{array}{l}\text { Final concentrations: } \\
10^{-6}, 5 \times 10^{-6}, 10^{-5} \mathrm{~g} / \mathrm{ml}\end{array}$ & $\begin{array}{l}\text { - Decreased amplitude of voltage-gated sodium current }\left(\mathrm{I}_{\mathrm{Na}}\right) \\
\text { of hippocampal CA1 neurons (observed within } 2 \text { min after } \\
\left.\text { AgNP treatment, } 10^{-5} \mathrm{~g} / \mathrm{ml}\right) \\
\text { - Extension of the recovery time of } \mathrm{I}_{\mathrm{Na}} \text { from inactivity } \\
\left(10^{-5} \mathrm{~g} / \mathrm{ml}\right)\end{array}$ & [80] \\
\hline $\begin{array}{l}\text { AgNPs: } \\
25,40 \text { and } 80 \\
n m\end{array}$ & $\begin{array}{l}\text { Primary } \\
\text { rat brain } \\
\text { microvessel } \\
\text { endothe- } \\
\text { lial cells } \\
\text { (rBMECs) }\end{array}$ & $\begin{array}{l}\text { Time of incubation: } \\
\quad 8 \text { or } 24 \mathrm{~h} \\
\text { Final concentration: } \\
\text { up to } 50 \mu \mathrm{g} / \mathrm{cm}^{3}\end{array}$ & $\begin{array}{l}\text { (Toxic effects observed for } 25 \mathrm{~nm} \text { AgNPs) } \\
\text { - Induction of release of IL-1 } \beta \text {, TNF- } \alpha \text { and PGE } \mathrm{E}_{2} \text { in rBMECs } \\
\text { - Increased BBB permeability } \\
\text { - Cellular damage with the appearance of large perfora- } \\
\text { tions in the monolayers } \\
\text { - Decreased cell viability (mainly for } 25 \text { and } 40 \mathrm{~nm} \text { AgNPs) }\end{array}$ & {$[137]$} \\
\hline $\begin{array}{l}\text { Peptide- coat- } \\
\text { ed AgNPs: } 20 \\
\text { and } 40 \mathrm{~nm} \text {, } \\
\text { AuNPs: } \\
20 \mathrm{~nm}\end{array}$ & $\begin{array}{l}\text { Mixed } \\
\text { primary cor- } \\
\text { tical neural } \\
\text { cell culture }\end{array}$ & $\begin{array}{l}\text { Time of incubation: } \\
\text { up to } 24 \mathrm{~h} \\
\text { Final concentrations: } \\
\text { 5, } 10,20,30,50 \\
\text { and } 100 \mu \mathrm{g} / \mathrm{ml}\end{array}$ & $\begin{array}{l}\text { (Toxic effects observed for } 20 \mathrm{~nm} \text { AgNPs) } \\
\text { - Increased ROS production, reduced by antioxidants (NAC) } \\
\text { - Formation of protein carbonyls } \\
\text { - Induction of heme oxygenase-1 expression } \\
\text { - Acute calcium response } \\
\text { - Dose-dependent decrease of cell viability }\end{array}$ & {$[52]$} \\
\hline $\begin{array}{l}\text { PVP-coated } \\
\text { AgNPs: } \\
75 \pm 20 \mathrm{~nm}\end{array}$ & $\begin{array}{l}\text { Astroglia- } \\
\text { rich primary } \\
\text { cultures }\end{array}$ & $\begin{array}{l}\text { Time of incubation: } \\
4 \mathrm{~h} \text { and further cultured } \\
\text { in AgNP-free medium } \\
\quad \text { for up to } 7 \text { days } \\
\text { Final concentrations: } \\
\text { 10, } 30 \text { and } 100 \mu \mathrm{M} \text { silver }\end{array}$ & $\begin{array}{l}\text { - Upregulation of metallothioneins in cells } \\
\text { - Unchanged total glutathione level and the GSSG/GSH } \\
\text { ratio } \\
\text { - No changes in cell viability } \\
\text { - No changes in ROS generation } \\
\text { - No changes in glucose consumption and lactate production } \\
\text { - No changes in extracellular concentration of glucose and } \\
\text { lactate }\end{array}$ & [85] \\
\hline $\begin{array}{l}\text { polyethylene } \\
\text { glycol-coated } \\
\text { AgNPs: } 5 \\
\pm 2 \mathrm{~nm}\end{array}$ & $\begin{array}{l}\text { Neuroendo- } \\
\text { crine cells } \\
\text { (chromaffin } \\
\text { cells) }\end{array}$ & $\begin{array}{l}\text { Final concentrations: } \\
\text { 13, 16, } 43,130 \mu \mathrm{M} \\
\text { and } 1.3 \mathrm{mM}\end{array}$ & $\begin{array}{l}\text { - Dose-dependent reduction of the amplitude of sodium } \\
\text { currents } \\
\text { - Induction of local changes in network activity }\end{array}$ & {$[14]$} \\
\hline $\begin{array}{l}\text { AgNPs: } \\
20 \mathrm{~nm}\end{array}$ & $\begin{array}{l}\text { Rat cortical } \\
\text { cells }\end{array}$ & $\begin{array}{l}\text { Time of incubation: } \\
\quad 2 \text { or } 3 \text { days } \\
\text { Final concentrations: } \\
1,5,10 \text { and } 50 \mu \mathrm{mg} / \mathrm{ml}\end{array}$ & $\begin{array}{l}\text { - Degeneration of cytoskeletal components ( } \beta \text {-tubulin, } \\
\text { F-actin) } \\
\text { - Inhibition of axonal outgrowth, reduction of the intensity } \\
\text { of neuronal branches and overlaps, and reduction of cell } \\
\text { viability of premature neurons and glial cells } \\
\text { - Decreased cell viability of neurons and glia at mature } \\
\text { stages of development } \\
\text { - Mitochondrial dysfunction leading to mitochondria- } \\
\text { dependent cell death } \\
\text { - Synaptic degeneration in cortical neurons (reduction of the } \\
\text { level of synaptic proteins: synaptophysin and PSD-95) }\end{array}$ & {$[144]$} \\
\hline $\begin{array}{l}\text { PVP-coated } \\
\text { AgNPs: from } \\
21.7 \pm 1.1 \mathrm{~nm} \\
\text { to } 24.4 \\
\pm 0.6 \mathrm{~nm}\end{array}$ & $\begin{array}{l}\text { Rat cerebel- } \\
\text { lar granule } \\
\text { cells } \\
\text { In vivo: neo- } \\
\text { natal rats }\end{array}$ & $\begin{array}{l}\text { Time of incubation: } \\
4 \text { or } 24 \mathrm{~h} \\
\text { Final concentration: } \\
\text { up to } 50 \mathrm{\mu g} / \mathrm{ml} \\
\text { In vivo: intranasally, } \\
21 \text { days of repeated } \\
\text { exposure; } \\
\text { dose: } 0.2 \text { or } 1 \mathrm{mg} / \mathrm{kg} \text { b.w. }\end{array}$ & $\begin{array}{l}\text { - Decreased cell viability (after } 24 \mathrm{~h} \text { incubation with } \\
\text { AgNPs at a concentration of } 0.05 \mathrm{\mu g} / \mathrm{ml} \text { ) } \\
\text { - Increased ROS production after } 4 \mathrm{~h} \text { exposure } \\
\text { - Depletion of reduced glutathione after } 4 \mathrm{~h} \text { incubation } \\
\text { - Induction of apoptosis after } 24 \mathrm{~h} \text { of incubation } \\
\text { - Increased intracellular calcium concentration } \\
\text { In vivo observations: } \\
\text { - Histopathological changes in cerebellum (alterations in } \\
\text { the morphology of the granular layer: granule cells with } \\
\text { abnormal shape and shrinking nucleus, degeneration } \\
\text { granular layer with loss and separation of structure, } \\
\text { edema and necrotic areas) } \\
\text { - Activation of caspase-3 }\end{array}$ & {$[146]$} \\
\hline
\end{tabular}


Table IV. Cont.

\begin{tabular}{|c|c|c|c|c|}
\hline $\begin{array}{l}\text { Type of } \\
\text { AgNPs }\end{array}$ & $\begin{array}{l}\text { Mammals/ } \\
\text { Cell lines }\end{array}$ & $\begin{array}{c}\text { Time of exposure, } \\
\text { dose }\end{array}$ & Observed neurotoxic effects & References \\
\hline $\begin{array}{l}\text { AgNPs: } \\
20 \mathrm{~nm}\end{array}$ & $\begin{array}{l}\text { Human } \\
\text { cerebral } \\
\text { cells: neu- } \\
\text { roblastoma } \\
\text { (SH-SY5Y), } \\
\text { astrocytoma } \\
\text { (D384); } \\
\text { human lung } \\
\text { epithelial } \\
\text { cells (A549) }\end{array}$ & $\begin{array}{l}\text { Short-term exposure: } \\
\text { 4, } 24 \text { and } 48 \mathrm{~h} \text {; final con- } \\
\text { centration: } 1-100 \mu \mathrm{g} / \mathrm{ml} \text {; } \\
\text { prolonged exposure: } \\
7 \text { and } 10 \text { days; final con- } \\
\text { centrations: } 0.5-50 \mu \mathrm{g} / \mathrm{ml}\end{array}$ & $\begin{array}{l}\text { - Dose- and time-dependent changes in mitochondri- } \\
\text { al metabolism and cell membrane damage leading to } \\
\text { decreased cell viability - observed for cerebral cell lines } \\
\text { after short-term exposure } \\
\text { - No significant changes in cell viability of A549 cells after } \\
\text { short-term exposure } \\
\text { - Dose-dependent reduction of proliferation ability and } \\
\text { capacity to form colonies after long-term exposure of } \\
\text { human cerebral cells and A549 cells to AgNPs }\end{array}$ & {$[20]$} \\
\hline $\begin{array}{l}\text { PVP-coated } \\
\text { AgNPs: } \\
<100 \mathrm{~nm}\end{array}$ & $\begin{array}{l}\text { Rat cerebel- } \\
\text { lar granule } \\
\text { cells }\end{array}$ & $\begin{array}{c}\text { incubation times: } \\
\text { 10, } 30 \text { and } 60 \mathrm{~min} \text {, } \\
\text { final concentrations: } \\
\quad 2.5-75 \mu \mathrm{g} / \mathrm{ml}\end{array}$ & $\begin{array}{l}\text { - Decreased cell viability after } 24 \mathrm{~h} \text { incubation }(50 \mathrm{\mu g} / \mathrm{ml}) \\
\text { - Dose-dependent increase in the uptake of radioactive } \\
\text { calcium after } 10 \text { min of incubation with the effect abol- } \\
\text { ished by an antagonist of NMDAR (MK-801) } \\
\text { - Dose-dependent increase in the intracellular calcium } \\
\text { concentration } \\
\text { - Activation of glutamatergic N-methyl-D-aspartate recep- } \\
\text { tors } \\
\text { - Increased ROS production after } 30 \text { min of incubation } \\
\text { with } 75 \mu g / m l \\
\text { - Decreased mitochondrial potential after } 60 \text { min of incu- } \\
\text { bation }\end{array}$ & {$[148]$} \\
\hline $\begin{array}{l}\text { AgNPs: } \\
3-5 \mathrm{~nm}\end{array}$ & $\begin{array}{c}\text { Mouse brain } \\
\text { neural cells: } \\
\text { murine } \\
\text { brain ALT } \\
\text { astrocytes, } \\
\text { murine } \\
\text { microglial } \\
\text { BV-2 cells, } \\
\text { mouse } \\
\text { neuro- } \\
\text { blastoma } \\
\text { Neuro-2a } \\
\text { cells }\end{array}$ & $\begin{array}{l}\text { time of incubation: } 24 \mathrm{~h} \text {, } \\
\text { final concentration: } 5,10 \text {, } \\
\qquad 12.5 \mu \mathrm{g} / \mathrm{ml}\end{array}$ & $\begin{array}{l}\text { - Increased IL-1 } \beta \text { secretion in microglial cells exposed to } \\
\text { AgNPs (dose: } 12.5 \mu \mathrm{g} / \mathrm{mL} \text { ) } \\
\text { - Increased gene expression of C-X-C motif chemokine } \\
13 \text { and macrophage receptor with collagenous structure } \\
\text { in all types of neural cells } \\
\text { - Increased expression of glutathione synthetase in micro- } \\
\text { glial cells and decreased in astrocytes } \\
\text { - Generation and deposition of amyloid- } \beta \text { (A } \beta \text { ) protein in } \\
\text { neuroblastoma cells (dose: } 12.5 \mu \mathrm{m} / \mathrm{ml} \text { ) } \\
\text { - Increased gene expression of amyloid precursor protein } \\
\text { (APP) in all neural cells and APP protein level in Neuro-2a } \\
\text { cells } \\
\text { - Decreased gene expression of LDLR (all types of neural } \\
\text { cells) and neprilysin (for neuroblastoma cells), decreased } \\
\text { LDLR protein level for A } \beta \text { uptake in Neuro-2a cells } \\
\text { exposed to AgNPs } \\
\text { - Decreased cell proliferation of astrocytes and Neuro-2a } \\
\text { cells with no change in microglial cells }\end{array}$ & {$[59]$} \\
\hline \multicolumn{5}{|c|}{ In vivo studies } \\
\hline $\begin{array}{l}\text { AgNPs: } \\
14 \mathrm{~nm}\end{array}$ & $\begin{array}{c}\text { Rats, } \\
\text { neuronal- } \\
\text { like PC12 } \\
\text { cells }\end{array}$ & $\begin{array}{c}\text { Oral: } 28 \text { days of repeated } \\
\text { exposure; } \\
\text { doses: } 4.5 \text { and } 9 \mathrm{mg} / \\
\text { kg b.w., } \\
\text { in vitro: } 4-48 \text { h of incu- } \\
\text { bation; } \\
\text { final concentrations: } \\
0.5,5 \text { and } 10 \mu g / m l\end{array}$ & $\begin{array}{l}\text { In vivo: } \\
\text { - Increased dopamine concentration in the brain (dose: } \\
4.5 \text { and } 9 \mathrm{mg} / \mathrm{kg} \text { b.w.) } \\
\text { - Increased 5-hydroxytryptamine (5-HT) concentration in } \\
\text { the brain (dose: } 9 \mathrm{mg} / \mathrm{kg} \text { b.w.) } \\
\text { - Unchanged noradrenaline concentration in brain } \\
\text { In vitro: } \\
\text { - Decreased viability of PC12 cells } \\
\text { - Induction of necrosis in PC12 not observed } \\
\text { - Induction of the mitochondrial and the death receptor } \\
\text { pathways }\end{array}$ & {$[54]$} \\
\hline $\begin{array}{l}\text { AgNPs: } \\
\text { 50-100 nm }\end{array}$ & Rats & $\begin{array}{l}\text { s.c.: single injection; } \\
\text { dose: } 62.8 \mathrm{mg} / \mathrm{kg} \text { b.w. }\end{array}$ & $\begin{array}{l}\text { - Histological changes (astrocyte swelling outside the } \\
\text { blood-brain barrier, presence of pyknotic and necrotic } \\
\text { neurons) }\end{array}$ & {$[135]$} \\
\hline
\end{tabular}


Table IV. Cont.

\begin{tabular}{|c|c|c|c|c|}
\hline $\begin{array}{l}\text { Type of } \\
\text { AgNPs }\end{array}$ & $\begin{array}{l}\text { Mammals/ } \\
\text { Cell lines }\end{array}$ & $\begin{array}{l}\text { Time of exposure, } \\
\text { dose }\end{array}$ & Observed neurotoxic effects & References \\
\hline $\begin{array}{l}\text { AgNPs: } \\
29.3 \\
\pm 12.5 \mathrm{~nm}\end{array}$ & Mice & $\begin{array}{l}\text { i.p.: single injection, dose: } \\
\text { 100, 500, } 1000 \mathrm{mg} / \mathrm{kg} \text { b.w. }\end{array}$ & $\begin{array}{l}\text { - Alterations in expression of oxidative stress-related } \\
\text { genes in various regions of the brain (caudate nucleus, } \\
\text { frontal cortex and hippocampus) }\end{array}$ & {$[112]$} \\
\hline $\begin{array}{l}\text { AlNPs, AgNPs, } \\
\text { CuNPs: } 50-60 \\
\mathrm{~nm}\end{array}$ & Rats, mice & $\begin{array}{l}\text { i.v.: single injection, } \\
\text { dose: } 30 \mathrm{mg} / \mathrm{kg} \text { b.w.; } \\
\text { i.p.: single injection, } \\
\text { dose: } 50 \mathrm{mg} / \mathrm{kg} \text { b.w.; } \\
\text { intracarotid: } \\
\text { single injection, dose: } \\
2.5 \mathrm{mg} / \mathrm{kg} \text { b.w.; and } \\
\text { intracerebroventricular: } \\
\quad 20 \mu \mathrm{mg} / 10 \mu \mathrm{l}\end{array}$ & $\begin{array}{l}\text { Effects observed after administration of AgNPs or CuNPs: } \\
\text { - Increased BBB permeability leading to brain edema for- } \\
\text { mation and decrease of local cerebral blood flow } \\
\text { - Glial cell activation } \\
\text { - Increased level of heat shock protein (HSP) } \\
\text { - Loss of myelinated fibers }\end{array}$ & [123] \\
\hline $\begin{array}{l}\text { AlNPs, AgNPs, } \\
\text { CuNPs: } 50-60 \\
\mathrm{~nm}\end{array}$ & Rats & $\begin{array}{l}\text { i.v.: single injection, } \\
\text { dose: } 30 \mathrm{mg} / \mathrm{kg} \text { b.w.; } \\
\text { i.p.: single injection, } \\
\text { dose: } 50 \mathrm{mg} / \mathrm{kg} \text { b.w.; and } \\
\text { intracerebroventricular: } \\
\quad 20 \mu \mathrm{g} / 10 \mu \mathrm{l}\end{array}$ & $\begin{array}{l}\text { - Increased BBB permeability leading to brain edema for- } \\
\text { mation caused by AgNPs, CuNPs }\end{array}$ & [124] \\
\hline $\begin{array}{l}\text { AgNPs: } 32.68- \\
380.21 \mathrm{~nm}\end{array}$ & Rats & $\begin{array}{l}\text { Nasal administration: } \\
\text { once every two days } \\
\text { for } 14 \text { days; } \\
\text { dose: } 3 \text { and } 30 \mathrm{mg} / \mathrm{kg} \text { b.w. }\end{array}$ & $\begin{array}{l}\text { - Deterioration of space learning and memory ability, } \\
\text { mainly in the group of animals exposed to } 30 \text { mg AgNPs/ } \\
\text { kg b.w. } \\
\text { - Increased ROS production in hippocampal homogenate } \\
\text { ( } 3 \text { and } 30 \mathrm{mg} / \mathrm{kg} \text { b.w.) } \\
\text { - Histological changes of pyramidal neurons in the PP } \\
\text { and DG regions of hippocampus (edema and nuclear } \\
\text { shrink phenomenon as well as neurobiosis among the } \\
\text { neurons) }\end{array}$ & [79] \\
\hline $\begin{array}{l}\text { AgNPs: } \\
36.3 \pm 1.2 \mathrm{~nm}\end{array}$ & Mice & $\begin{array}{l}\text { i.p.: } 7 \text { days of repeated } \\
\text { exposure; dose: } 10,25 \\
\text { and } 50 \mathrm{mg} / \mathrm{kg} \text { b.w. }\end{array}$ & $\begin{array}{l}\text { - No influence on spatial learning and memory } \\
\text { - Unmodified adult hippocampal neurogenesis (no chang- } \\
\text { es in hippocampal progenitor proliferation, new born cell } \\
\text { survival and differentiation) }\end{array}$ & {$[77]$} \\
\hline $\begin{array}{l}\text { citrate-coated } \\
\text { AgNPs: } \\
10 \pm 4 \mathrm{~nm}\end{array}$ & Rats & $\begin{array}{l}\text { Oral: } 14 \text { days of repeated } \\
\text { exposure; } \\
\text { dose: } 0.2 \mathrm{mg} / \mathrm{kg} \text { b.w. }\end{array}$ & $\begin{array}{l}\text { - Ultrastructural changes in synapses, mainly in hip- } \\
\text { pocampus (e.g. swelling of nerve endings, blurred struc- } \\
\text { ture of synaptic cleft, enhanced density of synaptic ves- } \\
\text { icles, disturbed synaptic membrane with free synaptic } \\
\text { vesicles located in neuropil, myelin-like bodies and mul- } \\
\text { ti-vesicular bodies) } \\
\text { - Decreased level of synaptic proteins: synaptophysin, } \\
\text { synapsin I and PSD- } 95\end{array}$ & {$[127]$} \\
\hline $\begin{array}{l}\text { citrate-coated } \\
\text { AgNPs: } \\
\text { 20-25 nm }\end{array}$ & $\begin{array}{l}\text { Neonatal } \\
\text { rats }\end{array}$ & $\begin{array}{l}\text { Intranasal instillation: } \\
14 \text { weeks of repeated } \\
\text { exposure; dose: } 0.1,0.2 \text {, } \\
0.5 \text { or } 1 \mathrm{mg} / \mathrm{kg} \text { b.w. }\end{array}$ & $\begin{array}{l}\text { - Significant body weight loss } \\
\text { - Histological changes (neuroglial cell activation with } \\
\text { destruction of the granular layer of the cerebellum) } \\
\text { - Increased level of glial fibrillary acidic protein (a marker } \\
\text { of astrocyte activation) } \\
\text { - Activation of caspase-3 }\end{array}$ & [147] \\
\hline
\end{tabular}

BBB - blood-brain barrier, b.w. - body weight, GSH - reduced glutathione, GSSG - oxidized glutathione, IL - interleukin, i.p. - intraperitoneal, i.v. - intravenous, $L D L R$ - low-density lipoprotein receptor, NAC - N-acetylcysteine, NMDAR - N-methyl-D-aspartate receptor, $P G E_{2}-$ prostaglandin $E_{2}, P S D$ - $95-$ postsynaptic receptor density protein, PVP - poly(N-vinylpyrrolidone), ROS - free radicals, TNF- $\alpha$-tumor necrosis factor-alpha 
barrier, and produce pyknotic and necrotic neurons [135]. The influence of nanoparticles on the integrity of the BBB after single intravenous ( $30 \mathrm{mg} / \mathrm{kg}$ b.w.), intraperitoneal $(50 \mathrm{mg} / \mathrm{kg}$ b.w.) and intracerebroventricular $(20 \mu \mathrm{g} / 10 \mu \mathrm{l})$ administration to rodents was investigated. Increased BBB permeability and brain edema formation [123,124], a marked decrease in local cerebral blood flow, glial cell activation and loss of myelinated fibers [123] were identified.

These limited studies have shown that AgNPs can induce BBB dysfunction and cause neuronal degeneration.

\section{AgNP toxicity towards neuronal cells}

The influence of AgNPs on neurons and glial cells has been predominately investigated using in vitro models. Many of the results show that exposure to AgNPs causes decreased cell viability, mainly of neurons $[20,52,54,59,137,144,146,148]$. In the case of astroglia-rich primary cultures, the results are generally inconsistent with either no changes in viability observed after incubation with AgNPs [85] or observations of high sensitivity [52]. Such differences are likely related to both the incubation time and the size of the AgNPs. Moreover, it was observed that AgNPs may negatively influence proliferation of human cerebral cells [20] and axonal outgrowth of premature neurons and glial cells [144].

Additionally, histopathological analysis of the cerebellum of neonatal rats exposed intranasally to AgNPs for 21 days showed many abnormalities including degeneration of the granular layer with loss of structure, edema and necrotic areas $[146,147]$. Similar changes were also identified in regions of rat hippocampus [79].

AgNPs can also cause changes in action potential, because they may lead to the reduction of the amplitude of voltage-gated sodium currents $[14,80] . \mathrm{Xu}$ and co-workers identified degeneration of cytoskeletal components ( $\beta$-tubulin and F-actin) and synaptic degeneration in cortical neurons [144]. Additionally, ultrastructural changes in synapses were observed in hippocampus of exposed rats together with decreased levels of two presynaptic proteins (synaptophysin and synapsin I) and one postsynaptic protein (PSD-95) [127].

The contribution of oxidative stress to the mechanisms of AgNP-mediated neurotoxicity has been considered. In in vitro studies of activation of ROS generation [52,146,148], protein carbonylation [52], induction of heme oxygenase-1 expression [52], and depletion of reduced glutathione concentration [146] were observed. However, loading of primary astrocytes with AgNPs did not cause significant alterations in total and reduced glutathione or ROS production [85]. Mitochondrial dysfunction caused by AgNPs $[144,148]$ and activation of caspase-3 $[54,146]$, which may result in mitochondria-dependent neuronal cell death $[54,144,146]$, have been reported. Limited in vivo studies also confirm the connection between AgNPs, oxidative stress and apoptosis in the central nervous system. It was demonstrated that AgNPs may cause up-regulation of oxidative stress-related genes in the brain tissues of mice after a single intraperitoneal injection [112], increased ROS production in rat hippocampus after 7 days of intranasal administration [79] and activation of caspase-3 [147]. However, the mechanisms of neurotoxicity of AgNPs may be more complex in the brain than in other tissues. Recently, new lines of research have indicated an influence of AgNPs on intracellular calcium homeostasis $[52,146,148]$. Moreover, it was suggested that calcium imbalance, resulting in neuronal cell death, may be connected to activation of glutamatergic receptors (NMDARs) [148]. This observation is in line with data showing impairment of cognitive functions of rats after prolonged intranasal exposure [79]. In contrast to the effect on neurons, protective mechanisms are induced in astrocytic cells. During exposure of primary astrocytes to AgNPs, metallothioneins (metal-binding proteins involved in cell protection against metal-induced toxicity) were shown to be upregulated [85].

Based on these findings, it is apparent that exposure to AgNPs exerts neurotoxic effects in mammals. However, the more subtle or permanent effects should be further investigated. Because our knowledge of the neurotoxic effects of AgNPs is based mainly on in vitro studies, future investigations should focus on animal studies. With increasing recognition of the dangers related to extensive usage of AgNPs and potential environmental hazards, we will be able to limit human health risks.

\section{Acknowledgments}

The study was supported partially by a statutory grant for Mossakowski Medical Research Centre, Polish Academy of Sciences, and by grant no. NN 401619938 from the Polish Ministry of Science and Higher Education. 


\section{References}

1. Ahamed M, Karns M, Goodson M, Rowe J, Hussain SM, Schlager JJ, Hong Y. DNA damage response to different surface chemistry of silver nanoparticles in mammalian cells. Toxicol Appl Pharmacol 2008; 233: 404-410.

2. Al Gurabi MA, Ali D, Alkahtani S, Alarifi S. In vivo DNA damaging and apoptotic potential of silver nanoparticles in Swiss albino mice. Onco Targets Ther 2015; 8: 295-302.

3. Ali D. Oxidative stress-mediated apoptosis and genotoxicity induced by silver nanoparticles in freshwater snail Lymnea luteola L. Biol Trace Elem Res 2014; 162: 333-341.

4. Allahverdiyev AM, Abamor ES, Bagirova M, Rafailovich M. Antimicrobial effects of $\mathrm{TiO}(2)$ and $\mathrm{Ag}(2) \mathrm{O}$ nanoparticles against drug-resistant bacteria and leishmania parasites. Future Microbiol 2011; 6: 933-940.

5. Almofti MR, Ichikawa T, Yamashita K, Terada H, Shinohara Y. Silver ion induces a cyclosporine a-insensitive permeability transition in rat liver mitochondria and release of apoptogenic cytochrome C. J Biochem 2003; 134: 43-49.

6. Arora S, Jain J, Rajwade JM, Paknikar KM. Cellular responses induced by silver nanoparticles: in vitro studies. Toxicol Lett 2008; 179: 93-100.

7. Asharani PV, Low Kah Mun G, Hande MP, Valiyaveettil S. Cytotoxicity and genotoxicity of silver nanoparticles in human cells. ACS Nano 2009; 3: 279-290.

8. ATSDR (Agency for Toxic Substances and Disease Registry). Toxicological Profile for Silver. Prepared by Clement International Corporation, under Contract 205-88-0608. U.S. Public Health Service 1990 ATSDR/TP-90-24.

9. Baram-Pinto D, Shukla S, Perkas N, Gedanken A, Sarid R. Inhibition of herpes simplex virus type 1 infection by silver nanoparticles capped with mercaptoethane sulfonate. Bioconjug Chem 2009; 20: 1497-1502.

10. Benn T, Cavanagh B, Hristovski K, Posner JD, Westerhoff P. The release of nanosilver from consumer products used in the home. J Environ Qual 2010; 39: 1875-1882.

11. Benn TM, Westerhoff P. Nanoparticle silver released into water from commercially available sock fabrics. Environ Sci Technol 2008; 42: 4133-4139.

12. Betteridge DJ. What is oxidative stress? Metabolism 2000; 49: 3-8.

13. Braydich-Stolle LK, Breitner EK, Comfort KK, Schlager JJ, Hussain SM. Dynamic characteristics of silver nanoparticles in physiological fluids: toxicological implications. Langmuir 2014; 30: 15309-15316.

14. Busse M, Stevens D, Kraegeloh A, Cavelius C, Vukelic M, Arzt E, Strauss DJ. Estimating the modulatory effects of nanoparticles on neuronal circuits using computational upscaling. Int J Nanomedicine 2013; 8: 3559-3572.

15. Carlson C, Hussain SM, Schrand AM, Braydich-Stolle LK, Hess KL, Jones RL, Schlager JJ. Unique cellular interaction of silver nanoparticles: size-dependent generation of reactive oxygen species. J Phys Chem B 2008; 112: 13608-13619.

16. Chae YJ, Pham CH, Lee J, Bae E, Yi J, Gu MB. Evaluation of the toxic impact of silver nanoparticles on Japanese medaka (Oryzias latipes). Aquat Toxicol 2009; 94: 320-327.
17. Chen X, Schluesener HJ. Nanosilver: a nanoproduct in medical application. Toxicol Lett 2008; 176: 1-12.

18. Christensen FM, Johnston HJ, Stone V, Aitken RJ, Hankin S, Peters S, Aschberger K. Nano-silver - feasibility and challenges for human health risk assessment based on open literature. Nanotoxicology 2010; 4: 284-295.

19. Clement JL, Jarrett PS. Antibacterial silver. Met Based Drugs 1994; 1: 467-482.

20. Coccini T, Manzo L, Bellotti V, De Simone U. Assessment of cellular responses after short- and long-term exposure to silver nanoparticles in human neuroblastoma (SH-SY5Y) and astrocytoma (D384) cells. ScientificWorldJournal 2014; 2014: 259765.

21. Cohen MS, Stern JM, Vanni AJ, Kelley RS, Baumgart E, Field D, Libertino JA, Summerhayes IC. In vitro analysis of a nanocrystalline silver-coated surgical mesh. Surg Infect (Larchmt) 2007; 8: 397-403

22. Costa CS, Ronconi JV, Daufenbach JF, Goncalves CL, Rezin GT, Streck EL, Paula MM. In vitro effects of silver nanoparticles on the mitochondrial respiratory chain. Mol Cell Biochem 2010; 342: 51-56.

23. Cronholm P, Karlsson HL, Hedberg J, Lowe TA, Winnberg L, Elihn K, Wallinder IO, Moller L. Intracellular uptake and toxicity of $\mathrm{Ag}$ and CuO nanoparticles: a comparison between nanoparticles and their corresponding metal ions. Small 2013; 9: 970-982.

24. Cushen M, Kerry J, Morris M, Cruz-Romero M, Cummins E. Evaluation and simulation of silver and copper nanoparticle migration from polyethylene nanocomposites to food and an associated exposure assessment. J Agric Food Chem 2014; 62: 1403-1411.

25. De Jong WH, Van Der Ven LT, Sleijffers A, Park MV, Jansen EH, Van Loveren $\mathrm{H}$, Vandebriel RJ. Systemic and immunotoxicity of silver nanoparticles in an intravenous 28 days repeated dose toxicity study in rats. Biomaterials 2013; 34: 8333-8343.

26. De Matteis V, Malvindi MA, Galeone A, Brunetti V, De Luca E, Kote S, Kshirsagar P, Sabella S, Bardi G, Pompa PP. Negligible particle-specific toxicity mechanism of silver nanoparticles: the role of Ag+ ion release in the cytosol. Nanomedicine 2015; 11: 731-739.

27. Dos Santos CA, Seckler MM, Ingle AP, Gupta I, Galdiero S, Galdiero M, Gade A, Rai M. Silver nanoparticles: therapeutical uses, toxicity, and safety issues. J Pharm Sci 2014; 103: 1931-1944.

28. Drake PL, Hazelwood KJ. Exposure-related health effects of silver and silver compounds: a review. Ann Occup Hyg 2005; 49: 575-585.

29. Dziendzikowska K, Gromadzka-Ostrowska J, Lankoff A, Oczkowski M, Krawczynska A, Chwastowska J, Sadowska-Bratek M, Chajduk E, Wojewodzka M, Dusinska M, Kruszewski M. Time-dependent biodistribution and excretion of silver nanoparticles in male Wistar rats. J Appl Toxicol 2012; 32: 920-928.

30. Ebabe Elle R, Gaillet S, Vide J, Romain C, Lauret C, Rugani N, Cristol JP, Rouanet JM. Dietary exposure to silver nanoparticles in Sprague-Dawley rats: effects on oxidative stress and inflammation. Food Chem Toxicol 2013; 60: 297-301.

31. Eby DM, Luckarift HR, Johnson GR. Hybrid antimicrobial enzyme and silver nanoparticle coatings for medical instruments. ACS Appl Mater Interfaces 2009; 1: 1553-1560. 
32. El Mahdy MM, Eldin TA, Aly HS, Mohammed FF, Shaalan MI. Evaluation of hepatotoxic and genotoxic potential of silver nanoparticles in albino rats. Exp Toxicol Pathol 2015; 67: 21-29.

33. Feng H, Pyykko I, Zou J. Hyaluronan up-regulation is linked to renal dysfunction and hearing loss induced by silver nanoparticles. Eur Arch Otorhinolaryngol 2015; 272: 2629-2642.

34. Feng QL, WU J, Chen GQ, Cui FZ, Kim TN, Kim JO. A mechanistic study of the antibacterial effect of silver ions on Escherichia coli and Staphylococcus aureus. I Biomed Mater Res 2000; 52: 662-668.

35. Foldbjerg R, Dang DA, Autrup H. Cytotoxicity and genotoxicity of silver nanoparticles in the human lung cancer cell line, A549. Arch Toxicol 2011; 85: 743-750.

36. Foldbjerg R, Olesen P, Hougaard M, Dang DA, Hoffmann HJ, Autrup H. PVP-coated silver nanoparticles and silver ions induce reactive oxygen species, apoptosis and necrosis in THP-1 monocytes. Toxicol Lett 2009; 190: 156-162.

37. Franco R, Sanchez-Olea R, Reyes-Reyes EM, Panayiotidis MI. Environmental toxicity, oxidative stress and apoptosis: menage a trois. Mutat Res 2009; 674: 3-22.

38. Gagne F, Auclair J, Turcotte P, Gagnon C. Sublethal effects of silver nanoparticles and dissolved silver in freshwater mussels. J Toxicol Environ Health A 2013; 76: 479-490.

39. Gaiser BK, Hirn S, Kermanizadeh A, Kanase N, Fytianos K, Wenk A, Haberl N, Brunelli A, Kreyling WG, Stone V. Effects of silver nanoparticles on the liver and hepatocytes in vitro. Toxicol Sci 2013; 131: 537-547.

40. Gajbhiye M, Kesharwani J, Ingle A, Gade A, Rai M. Fungus-mediated synthesis of silver nanoparticles and their activity against pathogenic fungi in combination with fluconazole. Nanomedicine 2009; 5: 382-386.

41. Gaki GS, Papavassiliou AG. Oxidative stress-induced signaling pathways implicated in the pathogenesis of Parkinson's disease. Neuromolecular Med 2014; 16: 217-230.

42. Galdiero S, Falanga A, Vitiello M, Cantisani M, Marra V, Galdiero M. Silver nanoparticles as potential antiviral agents. Molecules 2011; 16: 8894-8918.

43. Garcia-Contreras R, Argueta-Figueroa L, Mejia-Rubalcava C, Jimenez-Martinez R, Cuevas-Guajardo S, Sanchez-Reyna PA, Mendieta-Zeron $\mathrm{H}$. Perspectives for the use of silver nanoparticles in dental practice. Int Dent I 2011; 61: 297-301.

44. Garcia-Reyero N, Kennedy AJ, Escalon BL, Habib T, Laird JG, Rawat A, Wiseman S, Hecker M, Denslow N, Steevens JA, Perkins EJ. Differential effects and potential adverse outcomes of ionic silver and silver nanoparticles in vivo and in vitro. Environ Sci Technol 2014; 48: 4546-4555.

45. Garza-Ocanas L, Ferrer DA, Burt J, Diaz-Torres LA, Ramirez Cabrera M, Rodriguez VT, Lujan Rangel R, Romanovicz D, Jose-Yacaman M. Biodistribution and long-term fate of silver nanoparticles functionalized with bovine serum albumin in rats. Metallomics 2010; 2: 204-210.

46. Genter MB, Newman NC, Shertzer HG, Ali SF, Bolon B. Distribution and systemic effects of intranasally administered $25 \mathrm{~nm}$ silver nanoparticles in adult mice. Toxicol Pathol 2012; 40: 1004-1013.

47. Glick D, Barth S, Macleod KF. Autophagy: cellular and molecular mechanisms. J Pathol 2010; 221: 3-12.
48. Gliga AR, Skoglund S, Wallinder IO, Fadeel B, Karlsson HL. Size-dependent cytotoxicity of silver nanoparticles in human lung cells: the role of cellular uptake, agglomeration and Ag release. Part Fibre Toxicol 2014; 11: 11.

49. Gopinath P, Gogoi SK, Sanpui P, Paul A, Chattopadhyay A, Ghosh SS. Signaling gene cascade in silver nanoparticle induced apoptosis. Colloids Surf B Biointerfaces 2010; 77: 240-245.

50. Gordon O, Vig Slenters T, Brunetto PS, Villaruz AE, Sturdevant DE, Otto M, Landmann R, Fromm KM. Silver coordination polymers for prevention of implant infection: thiol interaction, impact on respiratory chain enzymes, and hydroxyl radical induction. Antimicrob Agents Chemother 2010; 54: 4208-4218.

51. Haase A, Arlinghaus HF, Tentschert J, Jungnickel H, Graf P, Mantion A, Draude F, Galla S, Plendl J, Goetz ME, Masic A, Meier W, Thunemann AF, Taubert A, Luch A. Application of laser postionization secondary neutral mass spectrometry/time-of-flight secondary ion mass spectrometry in nanotoxicology: visualization of nanosilver in human macrophages and cellular responses. ACS Nano 2011; 5: 3059-3068.

52. Haase A, Rott S, Mantion A, Graf P, Plendl J, Thunemann AF, Meier WP, Taubert A, Luch A, Reiser G. Effects of silver nanoparticles on primary mixed neural cell cultures: uptake, oxidative stress and acute calcium responses. Toxicol Sci 2012; 126: 457-468.

53. Hachicho N, Hoffmann P, Ahlert K, Heipieper HJ. Effect of silver nanoparticles and silver ions on growth and adaptive response mechanisms of Pseudomonas putida mt-2. FEMS Microbiol Lett 2014; 355: 71-77.

54. Hadrup N, Loeschner K, Mortensen A, Sharma AK, Qvortrup K, Larsen EH, Lam HR. The similar neurotoxic effects of nanoparticulate and ionic silver in vivo and in vitro. Neurotoxicology 2012; 33: 416-423.

55. Hancock JT, Desikan R, Neill SJ. Role of reactive oxygen species in cell signalling pathways. Biochem Soc Trans 2001; 29: 345-350.

56. Heydrnejad MS, Samani RJ, Aghaeivanda S. Toxic Effects of Silver Nanoparticles on Liver and Some Hematological Parameters in Male and Female Mice (Mus musculus). Biol Trace Elem Res 2015; 165: 153-158.

57. Hsin YH, Chen CF, Huang S, Shih TS, Lai PS, Chueh PJ. The apoptotic effect of nanosilver is mediated by a ROS- and JNK-dependent mechanism involving the mitochondrial pathway in NIH3T3 cells. Toxicol Lett 2008; 179: 130-139.

58. http://www.nanosilver.com.my/images/silversol/silverlSol-Coated-Glove.jpg.

59. Huang CL, Hsiao IL, Lin HC, Wang CF, Huang YJ, Chuang CY. Silver nanoparticles affect on gene expression of inflammatory and neurodegenerative responses in mouse brain neural cells. Environ Res 2015; 136: 253-263.

60. Hussain SM, Hess KL, Gearhart JM, Geiss KT, Schlager JJ. In vitro toxicity of nanoparticles in BRL 3A rat liver cells. Toxicol In Vitro 2005; 19: 975-983.

61. Ivask A, Kurvet I, Kasemets K, Blinova I, Aruoja V, Suppi S, Vija H, Kakinen A, Titma T, Heinlaan M, Visnapuu M, Koller D, Kisand V, Kahru A. Size-dependent toxicity of silver nanoparticles to bacteria, yeast, algae, crustaceans and mammalian cells in vitro. PLoS One 2014; 9: e102108.

62. Jiang X, Miclaus T, Wang L, Foldbjerg R, Sutherland DS, Autrup $\mathrm{H}$, Chen C, Beer C. Fast intracellular dissolution and per- 
sistent cellular uptake of silver nanoparticles in CHO-K1 cells: implication for cytotoxicity. Nanotoxicology 2015; 9: 181-189.

63. Jimenez-Lamana J, Laborda F, Bolea E, Abad-Alvaro I, Castillo JR, Bianga J, He M, Bierla K, Mounicou S, Ouerdane L, Gaillet S, Rouanet JM, Szpunar J. An insight into silver nanoparticles bioavailability in rats. Metallomics 2014; 6: 2242-2249.

64. Joshi N, Ngwenya BT, Butler IB, French CE. Use of bioreporters and deletion mutants reveals ionic silver and ROS to be equally important in silver nanotoxicity. J Hazard Mater 2015; 287: 51-58.

65. Kalishwaralal K, Barathmanikanth S, Pandian SR, Deepak V, Gurunathan S. Silver nanoparticles impede the biofilm formation by Pseudomonas aeruginosa and Staphylococcus epidermidis. Colloids Surf B Biointerfaces 2010; 79: 340-344.

66. Kim KT, Truong L, Wehmas L, Tanguay RL. Silver nanoparticle toxicity in the embryonic zebrafish is governed by particle dispersion and ionic environment. Nanotechnology 2013; 24: 115101.

67. Kim YS, Song MY, Park JD, Song KS, Ryu HR, Chung YH, Chang HK, Lee JH, Oh KH, Kelman BJ, Hwang IK, Yu IJ. Subchronic oral toxicity of silver nanoparticles. Part Fibre Toxicol 2010; 7: 20.

68. Lara HH, Ayala-Nunez NV, Ixtepan-Turrent L, Rodriguez-Padilla C. Mode of antiviral action of silver nanoparticles against HIV-1. J Nanobiotechnology 2010; 8: 1.

69. Lee J, Mahendra S, Alvarez PJ. Nanomaterials in the construction industry: a review of their applications and environmental health and safety considerations. ACS Nano 2010; 4: 3580-3590.

70. Lee JH, Kim YS, Song KS, Ryu HR, Sung JH, Park JD, Park HM, Song NW, Shin BS, Marshak D, Ahn K, Lee JE, Yu IJ. Biopersistence of silver nanoparticles in tissues from Sprague-Dawley rats. Part Fibre Toxicol 2013; 10: 36.

71. Lee TY, Liu MS, Huang LJ, Lue SI, Lin LC, Kwan AL, Yang RC. Bioenergetic failure correlates with autophagy and apoptosis in rat liver following silver nanoparticle intraperitoneal administration. Part Fibre Toxicol 2013; 10: 40.

72. Lee W, Kim KJ, Lee DG. A novel mechanism for the antibacterial effect of silver nanoparticles on Escherichia coli. Biometals 2014; 27: 1191-1201.

73. Lee Y, Kim P, Yoon J, Lee B, Choi K, Kil KH, Park K. Serum kinetics, distribution and excretion of silver in rabbits following 28 days after a single intravenous injection of silver nanoparticles. Nanotoxicology 2013; 7: 1120-1130.

74. Lee YH, Cheng FY, Chiu HW, Tsai JC, Fang CY, Chen CW, Wang YJ. Cytotoxicity, oxidative stress, apoptosis and the autophagic effects of silver nanoparticles in mouse embryonic fibroblasts. Biomaterials 2014; 35: 4706-4715.

75. Liau SY, Read DC, Pugh WJ, Furr JR, Russell AD. Interaction of silver nitrate with readily identifiable groups: relationship to the antibacterial action of silver ions. Lett Appl Microbiol 1997; 25: 279-283.

76. Likus W, Bajor G, Siemianowicz K. Nanosilver - does it have only one face? Acta Biochim Pol 2013; 60: 495-501.

77. Liu P, Huang Z, Gu N. Exposure to silver nanoparticles does not affect cognitive outcome or hippocampal neurogenesis in adult mice. Ecotoxicol Environ Saf 2013; 87: 124-130.

78. Liu W, Wu Y, Wang C, Li HC, Wang T, Liao CY, Cui L, Zhou QF, Yan B, Jiang GB. Impact of silver nanoparticles on human cells: effect of particle size. Nanotoxicology 2010; 4: 319-330.

79. Liu Y, Guan W, Ren G, Yang Z. The possible mechanism of silver nanoparticle impact on hippocampal synaptic plas ticity and spatial cognition in rats. Toxicol Lett 2012; 209: 227-231.

80. Liu Z, Ren G, Zhang T, Yang Z. Action potential changes associated with the inhibitory effects on voltage-gated sodium current of hippocampal CA1 neurons by silver nanoparticles. Toxicology 2009; 264: 179-184.

81. Loeschner K, Hadrup N, Qvortrup K, Larsen A, Gao X, Vogel U, Mortensen A, Lam HR, Larsen EH. Distribution of silver in rats following 28 days of repeated oral exposure to silver nanoparticles or silver acetate. Part Fibre Toxicol 2011; 8: 18.

82. Lok CN, Ho CM, Chen R, He QY, Yu WY, Sun H, Tam PK, Chiu JF, Che CM. Silver nanoparticles: partial oxidation and antibacterial activities. J Biol Inorg Chem 2007; 12: 527-534.

83. Loo CY, Young PM, Lee WH, Cavaliere R, Whitchurch CB, Rohanizadeh R. Non-cytotoxic silver nanoparticle-polyvinyl alcohol hydrogels with anti-biofilm activity: designed as coatings for endotracheal tube materials. Biofouling 2014; 30: 773-788.

84. Lu L, Sun RW, Chen R, Hui CK, Ho CM, Luk JM, Lau GK, Che CM. Silver nanoparticles inhibit hepatitis B virus replication. Antivir Ther 2008; 13: 253-262.

85. Luther EM, Schmidt MM, Diendorf J, Epple M, Dringen R. Upregulation of metallothioneins after exposure of cultured primary astrocytes to silver nanoparticles. Neurochem Res 2012; 37 : 1639-1648.

86. Massarsky A, Abraham R, Nguyen KC, Rippstein P, Tayabali AF, Trudeau VL, Moon TW. Nanosilver cytotoxicity in rainbow trout (Oncorhynchus mykiss) erythrocytes and hepatocytes. Comp Biochem Physiol C Toxicol Pharmacol 2014; 159: 10-21.

87. Massarsky A, Trudeau VL, Moon TW. Predicting the environmental impact of nanosilver. Environ Toxicol Pharmacol 2014; 38: 861-873.

88. Matsumura Y, Yoshikata K, Kunisaki S, Tsuchido T. Mode of bactericidal action of silver zeolite and its comparison with that of silver nitrate. Appl Environ Microbiol 2003; 69: 4278-4281.

89. Mizushima N. Autophagy: process and function. Genes Dev 2007; 21: 2861-2873.

90. Mody VV, Siwale R, Singh A, Mody HR. Introduction to metallic nanoparticles. J Pharm Bioallied Sci 2010; 2: 282-289.

91. Mohammed Fayaz A, Ao Z, Girilal M, Chen L, Xiao X, Kalaichelvan $P$, Yao $X$. Inactivation of microbial infectiousness by silver nanoparticles-coated condom: a new approach to inhibit HIVand HSV-transmitted infection. Int J Nanomedicine 2012; 7 : 5007-5018.

92. Monteiro-Riviere NA, Tran L. Safety implications of nanomaterial exposure to skin. In Nanotoxicology: Progress toward Nanomedicine. CRC Press, Boca Raton 2014; pp. 247-272.

93. Monteiro DR, Takamiya AS, Feresin LP, Gorup LF, De Camargo ER, Delbem AC, Henriques M, Barbosa DB. Susceptibility of Candida albicans and Candida glabrata biofilms to silver nanoparticles in intermediate and mature development phases. J Prosthodont Res 2015; 59: 42-48.

94. Morones JR, Elechiguerra JL, Camacho A, Holt K, Kouri JB, Ramirez JT, Yacaman MJ. The bactericidal effect of silver nanoparticles. Nanotechnology 2005; 16: 2346-2353.

95. Nishanth RP, Jyotsna RG, Schlager JJ, Hussain SM, Reddanna P. Inflammatory responses of RAW 264.7 macrophages upon expo- 
sure to nanoparticles: role of ROS-NFkappaB signaling pathway. Nanotoxicology 2011; 5: 502-516.

96. Nordberg GF, Gerhardsson L. Silver. In: Handbook on Toxicity of Inorganic Compounds. Seiler HG, Sigel H (eds.). Marcel Dekker, New York 1988; pp. 619-623.

97. Orlowski P, Tomaszewska E, Gniadek M, Baska P, Nowakowska J, Sokolowska J, Nowak Z, Donten M, Celichowski G, Grobelny J, Krzyzowska M. Tannic acid modified silver nanoparticles show antiviral activity in herpes simplex virus type 2 infection. PLoS One 2014; 9: e104113.

98. Palanisamy NK, Ferina N, Amirulhusni AN, Mohd-Zain Z, Hussaini J, Ping LJ, Durairaj R. Antibiofilm properties of chemically synthesized silver nanoparticles found against Pseudomonas aeruginosa. J Nanobiotechnology 2014; 12: 2.

99. Park EJ, Bae E, Yi J, Kim Y, Choi K, Lee SH, Yoon J, Lee BC, Park K. Repeated-dose toxicity and inflammatory responses in mice by oral administration of silver nanoparticles. Environ Toxicol Pharmacol 2010; 30: 162-168.

100. Park EJ, Yi J, Kim Y, Choi K, Park K. Silver nanoparticles induce cytotoxicity by a Trojan-horse type mechanism. Toxicol In Vitro 2010; 24: 872-878.

101. Park K, Park EJ, Chun IK, Choi K, Lee SH, Yoon J, Lee BC. Bioavailability and toxicokinetics of citrate-coated silver nanoparticles in rats. Arch Pharm Res 2011; 34: 153-158.

102. Park MV, Neigh AM, Vermeulen JP, De La Fonteyne LJ, Verharen $\mathrm{HW}$, Briede JJ, Van Loveren $\mathrm{H}$, De Jong WH. The effect of particle size on the cytotoxicity, inflammation, developmental toxicity and genotoxicity of silver nanoparticles. Biomaterials 2011; 32: 9810-9817.

103. Patlolla AK, Hackett D, Tchounwou PB. Silver nanoparticle-induced oxidative stress-dependent toxicity in Sprague-Dawley rats. Mol Cell Biochem 2015; 399: 257-268.

104. Pereira L, Dias N, Carvalho J, Fernandes S, Santos C, Lima N. Synthesis, characterization and antifungal activity of chemically and fungal-produced silver nanoparticles against Trichophyton rubrum. J Appl Microbiol 2014; 117: 1601-1613.

105. Persidsky Y, Ramirez SH, Haorah J, Kanmogne GD. Blood-brain barrier: structural components and function under physiologic and pathologic conditions. J Neuroimmune Pharmacol 2006; 1: 223-236.

106. Piao MJ, Kang KA, Lee IK, Kim HS, Kim S, Choi JY, Choi J, Hyun JW. Silver nanoparticles induce oxidative cell damage in human liver cells through inhibition of reduced glutathione and induction of mitochondria-involved apoptosis. Toxico Lett 2011; 201: 92-100.

107. Pohanka M. Alzheimer's disease and oxidative stress: a review. Curr Med Chem 2014; 21: 356-364.

108. Powers CM, Badireddy AR, Ryde IT, Seidler FJ, Slotkin TA. Silver nanoparticles compromise neurodevelopment in PC12 cells: critical contributions of silver ion, particle size, coating, and composition. Environ Health Perspect 2011; 119: 37-44.

109. Pulit J, Banach M, Szczyglowska R, Bryk M. Nanosilver against fungi. Silver nanoparticles as an effective biocidal factor. Acta Biochim Pol 2013; 60: 795-798.

110. Qureshi AT, Terrell L, Monroe WT, Dasa V, Janes ME, Gimble JM, Hayes DJ. Antimicrobial biocompatible bioscaffolds for orthopaedic implants. J Tissue Eng Regen Med 2014; 8: 386-395.
111. Rada B, Leto TL. Oxidative innate immune defenses by Nox/ Duox family NADPH oxidases. Contrib Microbiol 2008; 15 : 164-187.

112. Rahman MF, Wang J, Patterson TA, Saini UT, Robinson BL, Newport GD, Murdock RC, Schlager J), Hussain SM, Ali SF. Expression of genes related to oxidative stress in the mouse brain after exposure to silver-25 nanoparticles. Toxicol Lett 2009; 187: 15-21.

113. RAIS (The Risk Assessment Information System). Formal Toxicity Summary for silver. Prepared by: Rosmarie A. Faust, Ph.D., Chemical Hazard Evaluation and Communication Group, Biomedical and Environmental Information Analysis Section, Health and Safety Research Division, Oak Ridge, Tennessee, for the U.S. Department of Energy under Contract No. DE-AC05-84OR21400 1992

114. Rejeski D. Project on emerging Emerging Nanotechnologies. Woodrow Wilson International Center for Scholars, Washington 2011

115. Ribeiro F, Gallego-Urrea JA, Jurkschat K, Crossley A, Hassellov M, Taylor C, Soares AM, Loureiro S. Silver nanoparticles and silver nitrate induce high toxicity to Pseudokirchneriella subcapitata, Daphnia magna and Danio rerio. Sci Total Environ 2014; 466-467: 232-241.

116. Rinna A, Magdolenova Z, Hudecova A, Kruszewski M, Refsnes $M$, Dusinska $M$. Effect of silver nanoparticles on mitogen-activated protein kinases activation: role of reactive oxygen species and implication in DNA damage. Mutagenesis 2015; 30: 59-66.

117. Samuel U, Guggenbichler JP. Prevention of catheter-related infections: the potential of a new nano-silver impregnated catheter. Int J Antimicrob Agents 2004; 23 Suppl 1: S75-78.

118. Sanpui P, Chattopadhyay A, Ghosh SS. Induction of apoptosis in cancer cells at low silver nanoparticle concentrations using chitosan nanocarrier. ACS Appl Mater Interfaces 2011; 3: 218-228.

119. Sarhan OM, Hussein RM. Effects of intraperitoneally injected silver nanoparticles on histological structures and blood parameters in the albino rat. Int J Nanomedicine 2014; 9: 1505-1517.

120. SCENIHR (Scientific Committee on Emerging and Newly Identified Health Risks): Risk assessment of products of nanotechnologies, 2009.

121. Segal AW. How neutrophils kill microbes. Annu Rev Immunol 2005; 23: 197-223.

122. Setyawati MI, Yuan X, Xie J, Leong DT. The influence of lysosomal stability of silver nanomaterials on their toxicity to human cells. Biomaterials 2014; 35: 6707-6715.

123. Sharma HS, Ali SF, Hussain SM, Schlager JJ, Sharma A. Influence of engineered nanoparticles from metals on the bloodbrain barrier permeability, cerebral blood flow, brain edema and neurotoxicity. An experimental study in the rat and mice using biochemical and morphological approaches. J Nanosci Nanotechnol 2009; 9: 5055-5072.

124. Sharma HS, Hussain S, Schlager J, Ali SF, Sharma A. Influence of nanoparticles on blood-brain barrier permeability and brain edema formation in rats. Acta Neurochir Suppl 2010; 106: 359-364. 
125. Shrivastava S, Bera T, Roy A, Singh G, Ramachandrarao P, Dash D. Characterization of enhanced antibacterial effects of novel silver nanoparticles. Nanotechnology 2007; 18: 103-225.

126. Singh RP, Ramarao P. Cellular uptake, intracellular trafficking and cytotoxicity of silver nanoparticles. Toxicol Lett 2012; 213 249-259.

127. Skalska J, Frontczak-Baniewicz M, Struzynska L. Synaptic degeneration in rat brain after prolonged oral exposure to silver nanoparticles. Neurotoxicology 2015; 46: 145-154.

128. Sleiman HK, Romano RM, Oliveira CA, Romano MA. Effects of prepubertal exposure to silver nanoparticles on reproductive parameters in adult male Wistar rats. J Toxicol Environ Health A 2013; 76: 1023-1032.

129. Sondi I, Salopek-Sondi B. Silver nanoparticles as antimicrobial agent: a case study on E. coli as a model for Gram-negative bacteria. J Colloid Interface Sci 2004; 275: 177-182.

130. Song XL, Li B, Xu K, Liu J, Ju W, Wang J, Liu XD, Li J, Qi YF. Cytotoxicity of water-soluble mPEG-SH-coated silver nanoparticles in HL-7702 cells. Cell Biol Toxicol 2012; 28: 225-237.

131. Sung JH, Ji JH, Park JD, Yoon JU, Kim DS, Jeon KS, Song MY, Jeong J, Han BS, Han JH, Chung YH, Chang HK, Lee JH, Cho MH, Kelman BJ, Yu IJ. Subchronic inhalation toxicity of silver nanoparticles. Toxicol Sci 2009; 108: 452-461.

132. Sung JH, Ji JH, Yoon JU, Kim DS, Song MY, Jeong J, Han BS, Han JH, Chung YH, Kim J, Kim TS, Chang HK, Lee EJ, Lee JH, $\mathrm{Yu}$ IJ. Lung function changes in Sprague-Dawley rats after prolonged inhalation exposure to silver nanoparticles. Inhal Toxicol 2008; 20: 567-574.

133. Tamboli DP, Lee DS. Mechanistic antimicrobial approach of extracellularly synthesized silver nanoparticles against gram positive and gram negative bacteria. J Hazard Mater 2013; 260: 878-884

134. Tang J, Xiong L, Zhou G, Wang S, Wang J, Liu L, Li J, Yuan F, Lu S, Wan Z, Chou L, Xi T. Silver nanoparticles crossing through and distribution in the blood-brain barrier in vitro. J Nanosci Nanotechnol 2010; 10: 6313-6317.

135. Tang J, Xiong L, Wang S, Wang J, Liu L, Li J, Wan Z, Xi T. Influence of silver nanoparticles on neurons and blood-brain barrier via subcutaneous injection in rats. Appl Surf Sci 2008; 255: 502-504.

136. Topuz E, Sigg L, Talinli I. A systematic evaluation of agglomeration of $\mathrm{Ag}$ and $\mathrm{TiO} 2$ nanoparticles under freshwater relevant conditions. Environ Pollut 2014; 193: 37-44.

137. Trickler WJ, Lantz SM, Murdock RC, Schrand AM, Robinson BL, Newport GD, Schlager JJ, Oldenburg SJ, Paule MG, Slikker W, Jr., Hussain SM, Ali SF. Silver nanoparticle induced blood-brain barrier inflammation and increased permeability in primary rat brain microvessel endothelial cells. Toxicol Sci 2010; 118: 160-170.

138. Van Der Zande M, Vandebriel RJ, Van Doren E, Kramer E, Herrera Rivera Z, Serrano-Rojero CS, Gremmer ER, Mast J, Peters RJ, Hollman PC, Hendriksen PJ, Marvin HJ, Peijnenburg AA, Bouwmeester $\mathrm{H}$. Distribution, elimination, and toxicity of silver nanoparticles and silver ions in rats after 28-day oral exposure. ACS Nano 2012; 6: 7427-7442.

139. Vandebriel RJ, Tonk EC, De La Fonteyne-Blankestijn LJ, Gremmer ER, Verharen HW, Van Der Ven LT, Van Loveren $\mathrm{H}$,
De Jong WH. Immunotoxicity of silver nanoparticles in an intravenous 28-day repeated-dose toxicity study in rats. Part Fibre Toxicol 2014; 11: 21.

140. Volker C, Boedicker C, Daubenthaler J, Oetken M, Oehlmann J. Comparative toxicity assessment of nanosilver on three Daphnia species in acute, chronic and multi-generation experiments. PLoS One 2013; 8: e75026.

141. Vrcek IV, Zuntar I, Petlevski R, Pavicic I, Dutour Sikiric M, Curlin M, Goessler W. Comparison of in vitro toxicity of silver ions and silver nanoparticles on human hepatoma cells. Environ Toxicol 2014.

142. Wu J, Zheng Y, Song W, Luan J, Wen X, Wu Z, Chen X, Wang Q, Guo S. In situ synthesis of silver-nanoparticles/bacterial cellulose composites for slow-released antimicrobial wound dressing. Carbohydr Polym 2014; 102: 762-771.

143. Xiang D, Zheng Y, Duan W, Li X, Yin J, Shigdar S, O'Connor ML, Marappan M, Zhao X, Miao Y, Xiang B, Zheng C. Inhibition of A/Human/Hubei/3/2005 (H3N2) influenza virus infection by silver nanoparticles in vitro and in vivo. Int J Nanomedicine 2013; 8: 4103-4113

144. Xu F, Piett C, Farkas S, Qazzaz M, Syed NI. Silver nanoparticles (AgNPs) cause degeneration of cytoskeleton and disrupt synaptic machinery of cultured cortical neurons. Mol Brain 2013; 6: 29.

145. Xue Y, Zhang S, Huang Y, Zhang T, Liu X, Hu Y, Zhang Z, Tang M. Acute toxic effects and gender-related biokinetics of silver nanoparticles following an intravenous injection in mice. J Appl Toxicol 2012; 32: 890-899.

146. Yin N, Liu Q, Liu J, He B, Cui L, Li Z, Yun Z, Qu G, Liu S, Zhou Q, Jiang G. Silver nanoparticle exposure attenuates the viability of rat cerebellum granule cells through apoptosis coupled to oxidative stress. Small 2013; 9: 1831-1841.

147. Yin N, Yao X, Zhou Q, Faiola F, Jiang G. Vitamin E attenuates silver nanoparticle-induced effects on body weight and neurotoxicity in rats. Biochem Biophys Res Commun 2015; 458 : 405-410.

148. Zieminska E, Stafiej A, Struzynska L. The role of the glutamatergic NMDA receptor in nanosilver-evoked neurotoxicity in primary cultures of cerebellar granule cells. Toxicology 2014; 315: 38-48. 